\title{
Epigenetic Biomarkers of Preterm Birth and Its Risk Factors
}

\author{
Anna K. Knight ${ }^{1}$ and Alicia K. Smith ${ }^{1,2, *}$ \\ 1 Genetics and Molecular Biology Program, Emory University, Atlanta, GA 30322, USA; \\ anna.knight@emory.edu \\ 2 Department of Psychiatry \& Behavioral Sciences, Emory University School of Medicine, Atlanta, \\ GA 30322, USA \\ * Correspondence: alicia.smith@emory.edu; Tel.: +1-404-712-9582
}

Academic Editors: Jeffrey Craig and Thomas Mikeska

Received: 12 February 2016; Accepted: 8 April 2016; Published: 13 April 2016

\begin{abstract}
A biomarker is a biological measure predictive of a normal or pathogenic process or response. Biomarkers are often useful for making clinical decisions and determining treatment course. One area where such biomarkers would be particularly useful is in identifying women at risk for preterm delivery and related pregnancy complications. Neonates born preterm have significant morbidity and mortality, both in the perinatal period and throughout the life course, and identifying women at risk of delivering preterm may allow for targeted interventions to prevent or delay preterm birth (PTB). In addition to identifying those at increased risk for preterm birth, biomarkers may be able to distinguish neonates at particular risk for future complications due to modifiable environmental factors, such as maternal smoking or alcohol use during pregnancy. Currently, there are no such biomarkers available, though candidate gene and epigenome-wide association studies have identified DNA methylation differences associated with PTB, its risk factors and its long-term outcomes. Further biomarker development is crucial to reducing the health burden associated with adverse intrauterine conditions and preterm birth, and the results of recent DNA methylation studies may advance that goal.
\end{abstract}

Keywords: epigenetics; biomarker; preterm birth; methylation; pregnancy; gestation

\section{Introduction}

The prenatal environment has become increasingly recognized as an important predictor of immediate and long-term risk for chronic conditions, but there are few biological markers that identify those at risk for common pregnancy complications, such as preterm birth (PTB). Early identification of mothers at increased risk for preterm delivery or of children at risk of developmental consequences resulting from preterm birth may facilitate effective prenatal or postnatal interventions. Even in the absence of a fully effective preventative treatment for PTB, measures can be taken to mitigate risk for the mother and fetus. Potential interventions for the mother may include preemptive monitoring and preparation for labor in a facility prepared to care for high-risk women and neonates. Mothers who are more likely to deliver preterm may also benefit from prenatal social support programs. Interventions for the fetus may include the anticipation of clinical interventions to limit complications common in preterm infants as well as early participation in developmental enrichment programs [1]. Over the past several years, the availability of cost-effective methods for assessing the epigenome has led to identification of epigenetic signatures of the intrauterine environment including exposure to medication, stress, gestational length, and smoking [2-13]. Evaluation of the genes containing these differentially methylated sites is not only useful for identifying biological pathways regulated in each circumstance, but it may also facilitate identification of clinically informative biomarkers. 
A biomarker is a biological measure that is predictive of a normal or pathogenic process or response. In clinical practice, biomarkers can be used for risk assessment, early detection or onset of a disease or chronic illness. Once a diagnosis is established, they can also be used as an indicator of symptom severity or response to treatment [14-16]. In general, a biomarker candidate must be reproducible and have sufficient sensitivity and specificity to provide clinically-relevant information [17].

Many factors influence the prenatal environment, and this review is not meant to extensively cover all of them. We will focus on recent epigenetic studies of preterm birth and environmental factors that increase maternal risk for PTB and infant risk for chronic conditions across the lifespan including maternal perinatal nutrition, substance use, and stress (Figure 1). Certainly there are more epigenetic studies of these risk factors during the perinatal period than studies of PTB. Potential contributors to PTB influence gene regulation, are amenable to intervention, and have significant impacts on the future health of both the mother and child. Identification of biomarkers for these environmental risk factors would provide insight into the mechanisms underlying changes in DNA methylation that may be indicative of future health risk. Understanding how environmental risk factors affect DNA methylation would allow us to evaluate proposed biomarkers for PTB, separating out its clinical presentation from its risk factors. It should also be noted that many of environmental risk factors are related, a concept that is rarely addressed in studies that assess single risk factors in isolation. Thus, an epigenetic biomarker encompassing multiple indicators of the perinatal environment would be particularly valuable for reducing morbidity and mortality from PTB and related conditions. As of now, such a biomarker does not exist, but recent studies have made substantial progress towards this goal.

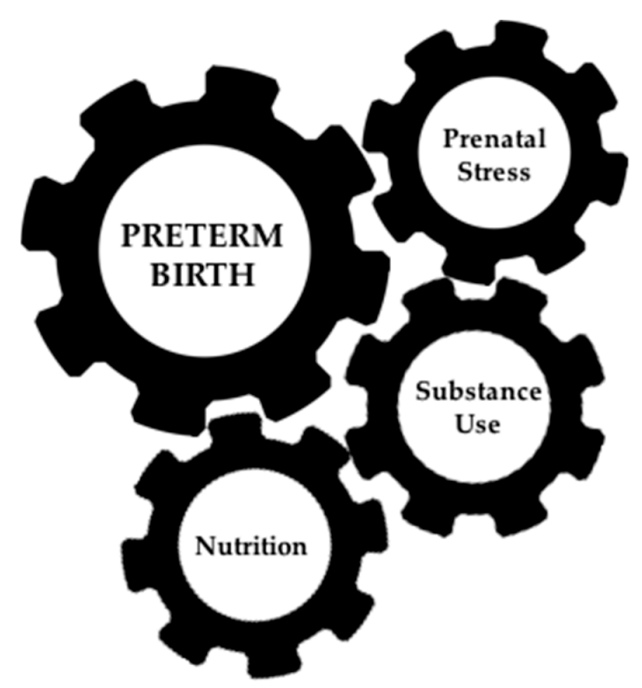

Figure 1. Nutrition, substance use and stress during pregnancy increase risk for spontaneous preterm birth. Each of these risk factors has been associated with DNA methylation differences that may be informative for early prediction and treatment.

\section{Preterm Birth}

\subsection{Health Burden of Preterm Birth}

In 2013, $11.39 \%$ of neonates in the United States were born preterm (before 37 weeks gestation) [18]. PTB is the leading cause of infant mortality, accounting for $\sim 35 \%$ of infant deaths, and contributes to disability among survivors [19]. Over the first week of life, a substantial fraction of deaths in neonates without congenital malformations result from PTB [20,21]. Children born preterm are more likely to have cerebral palsy, sensory deficits, learning disabilities, and respiratory illnesses [20,21]. PTB also increases the risk of being hospitalized with infections during childhood [22]. Among school aged children, those born preterm show diminished cognitive performance, increased externalizing and 
internalizing behaviors and are more likely to develop ADHD [23]. PTB and reduced fetal growth have also been linked to a number of important chronic diseases of adulthood such as type 2 diabetes [24,25]. Additionally, mothers who deliver preterm experience an increased risk of developing cardiovascular disease, type II diabetes, and breast cancer later in life [26-29]. Thus, PTB has substantial implications for the future health of both the mother and the neonate.

PTB is a heterogeneous condition, with three clinical types: medically indicated PTB, premature rupture of membranes (pPROM), and spontaneous preterm birth. Approximately $30 \%-35 \%$ of PTB is medically indicated due to a condition that places the mother or fetus at risk, including preeclampsia and fetal growth restriction [30,31]. pPROM accounts for another $25 \%-30 \%$ of PTB and occurs when the amniotic sac ruptures prematurely and more than an hour before the onset of contractions. [30]. Finally, spontaneous preterm birth refers to spontaneous labor and subsequent delivery before 37 weeks gestation, and accounts for between $23 \%$ and $64 \%$ of PTB. The underlying mechanisms of spontaneous PTB and pPROM are unknown [32]. Each type of PTB may have a unique biological signature, though there are likely to be common pathways as well because there are overlapping risk factors between the different types of PTB [33,34]. The idea that a single biomarker could be informative for different types of PTB is supported by a recent study examining DNA methylation in spontaneous PTB, pPROM, and medically indicated PTB that found no differences in eight candidate genes based on the type of PTB [35].

Mechanisms contributing to PTB have been recently reviewed in depth [36-39]. Briefly, spontaneous PTB has a range of contributing risk factors including infection, undernutrition, stress and substance use [39]. Two of the most common pathways linking these risk factors to preterm birth include: (1) activation of inflammatory and neuroendocrine pathways in response to stress, or stress-related behaviors such as smoking, resulting in upregulation of inflammatory cytokine production; and (2) activation of a cytokine-prostaglandin cascade in response to infection [21]. In this review, we will focus on spontaneous PTB where possible, though studies often do not distinguish between the different types of PTB or rely solely on gestational ages.

\subsection{Epigenetics and Preterm Birth}

The pathways underlying the associations between future neonatal development and future maternal disease risk with PTB remain unclear, but epigenetic dysregulation may contribute to a substantial part of this risk [36]. The most widely studied epigenetic change impacted by the environment is DNA methylation, a modification characterized by the addition of a methyl group to the $5^{\prime}$ position of a cytosine in a cytosine guanine dinucleotide $(\mathrm{CpG})$ site. Typically, an increase in DNA methylation at promoter regions correlates with a decrease in expression of that gene, though exceptions to this are commonly documented [40]. Intragenic DNA methylation is also important to regulate alternative promoters and enhancers that define a variety of alternative transcripts and promote gene expression [41].

Microarrays and next generation sequencing have allowed examination of DNA methylation on a genome-wide scale. Due to this, several recent papers have examined the associations between the epigenome and PTB. Three studies have identified CPG sites related to PTB using neonatal blood [42-44]. Parets and colleagues found 29 CpG sites that were associated with spontaneous PTB independent of gestational age in a case-control study of 50 African American neonates. Several of these $\mathrm{CpG}$ sites were located in genes associated with development and the Notch signaling pathway. Additionally, $9637 \mathrm{CpG}$ sites were associated with gestational age and were enriched among genes involved in embryonic development and the extra-cellular matrix [42]. The study by Cruickshank and colleagues identified 1555 CpG sites associated with PTB (no specific type defined) in 12 term and 12 preterm neonates, but did not adjust for gestational age. Interestingly, they found that most differences between term and preterm neonates observed at birth were no longer detectable at age 18 [43]. In a similarly powered study, Fernando and colleagues identified 1855 sites associated with spontaneous PTB from cord blood, 196 of which were independent of gestational age. These 196 sites 
were enriched for pathways associated with contractions and labor, but none of them overlapped with the 29 PTB-associated sites from the previous study of African American neonates. However, 157 differentially methylated sites overlapped with the Cruickshank analysis of PTB [44].

These studies support that there are DNA methylation differences in neonates born preterm, but there have been few studies examining methylation differences in mothers that deliver preterm. One recent study identified thousands of $\mathrm{CPG}$ sites in which neonatal methylation could be predicted from maternal methylation and that these correlated patterns were enriched among biological pathways implicated in PTB and chronic diseases [45]. These findings are supported by a recent study that examined maternal gene expression, which is often regulated by DNA methylation, related to preterm labor; 469 genes were differentially expressed in 106 women delivering preterm compared to 48 women with threatened preterm labor. In general, women with threatened preterm labor have persistent contractions, though only a small fraction will deliver within ten days. The genes identified were enriched for several pathways, including stress response and mRNA processing [46]. These findings suggest that there are substantial changes in gene regulation that can be detected in mothers prior to delivery in fetal or maternal tissues. Due to the current paucity of research in this area, future studies are needed to delineate the relationship between maternal gene regulation and PTB.

Although few studies have examined maternal blood for PTB-related epigenetic biomarkers, there are numerous studies examining the utility of other types of biomarkers in maternal serum such as cytokines and other metabolites [37,47-53]. One of the most widely reported serum biomarkers, alpha-fetoprotein, is currently used in prenatal screening and has been associated with increased risk of pregnancy complications, including PTB, as early as the second trimester $[48,52,53]$. These studies have shown promising associations. Because DNA methylation often regulates the expression of genes that encode proteins, biomarkers that assess methylation may allow for earlier identification of those at increased risk for delivering preterm. DNA methylation, unlike proteins, are also more amenable to screening with high-throughput panels that utilize standardized chemistry, and may allow for more rapid and reproducible assessment of multiple biomarkers. There have been several arguments for the use of methylation-based biomarkers for pregnancy complications, including preterm birth [54-56].

\section{Developmental Origins of Health and Disease}

Maternal behavior and environmental conditions can have a significant impact on the developing fetus through "fetal programming". The Developmental Origins of Health and Disease (DOHaD) hypothesis was first proposed by David Barker after examining the association between birthweight and death rates in England and Wales [57]. The DOHaD hypothesis proposes that the uterine environment programs the fetus for environmental challenges that he or she is likely to experience after birth [57]. Thus, the uterine environment is crucial for long-term health and development, and identifying indicators of adverse uterine environments through the use of biomarkers may allow targeted interventions to change modifiable behaviors or mediate the negative effects of that environment.

A seminal example of prenatal programming affecting the exposed neonate after birth is the case of the Dutch Hunger Winter. Neonates exposed to this famine between 1944 and 1945 have experienced lasting effects on their health. [58-62]. One of the first studies on this cohort was published in 1976, when the exposed neonates would have been 19 years of age. This study by Ravelli and colleagues revealed that the timing of famine exposure greatly impacted future health, with men exposed to famine in the first and second trimesters more likely to be obese at age 19, and men exposed to famine during the third trimester experienced obesity at a much lower rate through age 19 [58]. Since 1976, a plethora of follow-up studies have been published on this cohort. In addition to the findings of Ravelli and colleagues, subsequent studies have seen associations between famine exposure and PTB, low birth weight (LBW), neural defects, schizophrenia spectrum disorders, addiction in men, impaired glucose tolerance, and earlier occurrence of menopause [59-62].

Recent studies, including several presented in this review, have explored the plausibility of developmental programming taking place through epigenetic changes associated with the prenatal 
environment [63]. The myriad of health consequences associated with prenatal exposure to famine provides evidence in support of the $\mathrm{DOHaD}$ hypothesis. For example, severe undernutrition, such as in the case of the Dutch Hunger Winter, has also been associated with changes in methylation, in addition to its associations with weight, neurological and endocrine consequences [64]. Tobi and colleagues examined methylation at 15 candidate loci in this population. They found changes in methylation at several imprinted and non-imprinted genes with functions related to metabolic and cardiovascular disease as compared to siblings not exposed to famine [64]. Imprinted genes provide a unique opportunity to measures changes in DNA methylation as silencing of the imprinted allele occurs early in development and is stably transmitted [65]. Thus, when one allele in a diploid cell is imprinted, the differentially methylated regions (DMRs) should exhibit 50\% methylation under normal circumstances, allowing changes in methylation due to the intrauterine environment to be readily detected [65]. These results indicate that famine during the prenatal period can have lasting effects on the epigenome of the fetus, and future studies should evaluate the methylation of these genes in undernourished populations. The DOHaD hypothesis is further illustrated in a recent study by Silver and colleagues [66]. They found that the methylation at a metastable epiallele, vault RNA 2-1 (VTRNA2-1), was associated with season of conception and maternal nutrition in rural Gambia, suggesting that the early prenatal environment can "program" fetal methylation that is stable long-term [66]. Future studies identifying other stable methylation changes associated with the periconceptional environment and factors contributing to preterm birth are needed and may provide candidate biomarkers predictive of the intrauterine environment and long-term health risks through adulthood.

\section{Nutrition}

\subsection{Maternal BMI}

Maternal over and undernutrition can have significant impacts on pregnancy outcome for both the mother and fetus [67-73]. The primary maternal outcome associated with low maternal body mass index (BMI) was delivering preterm [67]. The risk of delivering preterm was associated with the degree of maternal undernutrition, but this association could be mitigated by appropriate weight gain during pregnancy [67]. Low maternal BMI is also associated with fetal growth restriction [67-69].

Sharp and colleagues performed an epigenome-wide association study (EWAS) for associations between DNA methylation and maternal BMI in the Avon Longitudinal Study of Parents and Children cohort. They found $1621 \mathrm{CpG}$ sites associated with low maternal BMI in offspring, though no sites were associated with gestational weight gain [9]. When examining long-term offspring adiposity in childhood and adolescence, hypomethylated sites tended to be positively associated with adiposity in children born to underweight mothers and negatively associated with adiposity in children born to overweight mothers. Hypermethylated sites tended to be negatively associated with adiposity in children born to underweight mothers and positively associated in children born to overweight mothers. However, only one $\mathrm{CpG}$ site was differentially methylated based on adiposity at both birth and adolescence.

The rate of PTB in obese women is lower than in the general population [68]. However, high maternal BMI is also associated with preeclampsia and ensuing preterm delivery, gestational diabetes, and hypertension. High maternal BMI also associated with increased risk of cesarean section, prolonged hospital stay, and postpartum hemorrhage in the mother and increased risk of stillbirth, macrosomy, low Apgar score, meconium aspiration, seizures and cerebral palsy in the neonate. $[68,69,73-76]$. In an analysis of population attributable risk fractions, Oteng-Ntim and colleagues found that eliminating or reducing maternal obesity could circumvent a significant proportion of negative outcomes [77].

Numerous studies have examined the link between overweight and obese mothers and offspring DNA methylation [78-80]. Nomura and colleagues found that maternal obesity is associated with decreased global methylation in the placenta, but not in umbilical cord blood, raising the question of which tissues should be interrogated when examining the association between maternal obesity and 
fetal methylation, though the issue of tissue specificity is broadly relevant to all EWAS studies [78]. They also saw an association between placental hypermethylation and two neonatal outcomes: smaller head circumference and shorter body length [78]. However, another recent study did not see an association between global methylation and maternal BMI in either the placenta or cord blood [79].

Liu and colleagues examined DNA methylation and maternal BMI in a cohort of African American women and found that male and female neonates displayed distinct associations at different $\mathrm{CpG}$ sites, though none remained significant after multiple test correction [80]. Even so, they raise the point that many of the CPG sites approaching significance for association between maternal BMI and child methylation have previously been implicated in a variety of biological pathways significant in the development of cancer and other chronic diseases [80].

Maternal obesity may influence offspring outcome by altering the immune system of both the mother and the fetus $[70,72,81-84]$. Obesity is associated with increased cytokine production, and may alter nutrient transport and placental vasculature $[70,72,81,82]$. Cytokine exposure may also alter gene expression or epigenetic marks in the fetus, eventually leading to altered brain development and increased risk for obesity, though the mechanistic link between cytokines and these outcomes is unclear [81].

Weight loss has profound effects for the health of the mother and the fetus, as seen through studies on the effects of gastric bypass surgery $[85,86]$. In addition to weight loss, gastric bypass surgery has been associated with reduction in rates of type II diabetes, hypertension, and hyperlipidemia, and these comorbidities are associated with pregnancy complications for the mother and fetus [87-89]. Gastrointestinal bypass surgery provides an opportunity to examine methylation difference in siblings conceived before and after surgery [86]. Offspring born after maternal surgery are less obese and have better cardiovascular risk profiles than their siblings born before surgery [86]. There is also a significant difference in the methylation profiles of siblings born before and after surgery, after adjusting for age, with 14,466 CpG sites in 5698 genes being differentially methylated between sibling groups. The 5698 genes were enriched in pathways related to autoimmune, pancreas, and glucose metabolism disorder [86]. This implies that maternal weight loss may have enormous implications for the methylome of her offspring, as well as their future health. CpG sites associated with weight loss should be examined for associations with the offspring outcomes in mothers not undergoing surgery to identify whether methylation at these $\mathrm{CpG}$ sites mediates the relationship between maternal weight, child obesity and cardiovascular risk profiles. If these $\mathrm{CpG}$ sites are found to mediate the relationship, they may serve as potential epigenetic biomarkers to identify and monitor children at risk for childhood obesity and cardiovascular risk factors so that preventive steps may be taken.

\subsection{Folate}

Folate is recommended during pregnancy to prevent neural tube defects [90,91]. Folate deficiency is associated with maternal depression, bacterial vaginosis, and preeclampsia, all of which increase risk for PTB, although the association between folate levels and preeclampsia is controversial [92-96]. Folate supplementation has also been shown to positively impact the fetus by decreasing rates of PTB as well as being born with low birth weight and small for gestational age [92-95,97-99]. Despite the success of folate supplementation in reducing neural tube defects, it may be associated with other fetal complications including cleft lip/alveolus and bronchiolitis [100,101].

The role of folate intake during pregnancy and its impact on offspring outcome and epigenetics has been widely studied [102-106]. Folate is a methyl donor, and methyl donor deficiency correlates with changes in DNA methylation [102-106]. Folate supplementation use after 12 weeks gestation has been associated with differences in global methylation (LINE1) and methylation patterns of imprinted genes (IGF2, PEG3) [107-109]. These associations are present in both in maternal and umbilical cord blood [107]. More research into the potential correlations between altered methylation at these sites and neonatal outcomes is needed. It is possible that hypomethylation of LINE1 elements could lead to genomic instability by mobilizing transposable elements. Similarly, aberrant methylation of imprinted 
regions has previously been associated with cancer, infertility, and transient neonatal diabetes, among others $[107,110-112]$.

Hoyo and colleagues did not see a relationship between folate supplementation in IGF2, but H19 methylation was significantly decreased with folate supplementation in male neonates [103]. There was no association with folate supplementation in females [103]. Ba and colleagues also saw no changes in IGF2 methylation associated with folate supplementation, although methylation was impacted by levels of vitamin B12 [113]. Despite these discordant findings, examining differential methylation in genes known to associate with folate levels may be useful for personalizing folate doses to better balance the risk associated with too much or too little folate intake.

\subsection{Vitamin D}

Vitamin D deficiency in pregnancy has been associated with increased incidence of PTB, small for gestational age, and low birth weight in neonates [114-118]. A recent meta-analysis did not see a positive change in PTB, LBW, pre-eclampsia, and gestational diabetes rates with vitamin D supplementation, though they did conclude that vitamin D has "plausible effects" on many perinatal outcomes [119]. Maternal vitamin D levels during pregnancy also predict long-term outcomes for the child including congenital rickets, smaller arm muscle and higher insulin resistance, autism spectrum disorders, and asthma in childhood. Higher levels of vitamin D is associated with higher fasting insulin, cholesterol, and triglyceride concentrations in adults [120-124].

The largest predictor of circulating vitamin D levels in neonates is the circulating vitamin D levels of their mothers [125]. Circulating vitamin D is converted to 1,25-dihydroxyvitamin D (25-OHD), and can be further converted into its hormonal form, 1,25(OH)2D. This is typically accomplished in the kidneys, but the placenta is also capable of synthesizing 1,25(OH)2D [126]. 1,25(OH)2D then binds the vitamin $\mathrm{D}$ receptor, which can subsequently act as a transcription factor by targeting the vitamin $\mathrm{D}$ response element (VDRE) motif within the promoter of the target gene to affect gene expression [126].

Vitamin D Binding Protein (VDBP) has recently been assessed as a biomarker of preterm labor, and shows promise as a potential predictor $[127,128]$. Liong and colleagues found that cervicovaginal fluid concentrations of VDBP were elevated in the days preceding labor relative to the rest of pregnancy [127]. Women who delivered preterm were also found to have higher baseline levels of VDBP. They concluded that VDBP levels had high positive and negative predictive values ( $82.8 \%$ and $95.3 \%)$ [127]. In a subsequent study, when combining VDBP and albumin levels, the positive and negative predictive values increased $(100 \%$ and $96.7 \%)$ [128].

The effects of maternal vitamin D levels may influence perinatal and long-term outcomes through immune, antibacterial, and anti-inflammatory responses [99,129]. A recent study has found associations between vitamin D levels in maternal and cord blood and immune cell type proportions, as well as placental expression of immune system related genes [130]. Interestingly, vitamin D deficiency was also associated with downregulation of the expression of vitamin D receptor (VDR), FOXP3 (a transcription factor associated with Treg cells), and retinoic acid receptor (RAR). It was also associated with upregulation of the expression of $V D R B$, complement receptors $C D 21$ and $C D 23$, and a Vitamin D regulatory enzyme (CYP24A1) in the placenta [130].

Of note, 25-OH-D concentrations may themselves serve as a biomarker for negative outcomes, especially preterm birth and preeclampsia, although these associations are controversial [119,131-133]. Accumulating data support that vitamin D deficiency plays a role in disparities in reproductive health outcomes [132,134]. A recent study reported that methylation of a subset of CpG sites identified through a network analysis is affected by both ancestry and maternal vitamin D concentrations, suggesting that both of these factors may impact the methylome of the neonate [135]. 


\section{Substance Use}

\subsection{Maternal Smoking during Pregnancy}

Smoking is a well-known, preventable, significant contributor to neonatal and maternal morbidity and mortality, yet $12.3 \%$ of pregnant women smoked in 2010 [136]. Smoking may cause complications for the fetus due to exposure to tobacco toxins, poor umbilical blood flow, oxidative stress, and changes in gene expression [137-139]. Conditions associated with maternal smoking in pregnancy for the neonate include PTB, fetal growth restriction, sudden infant death syndrome, stillbirth, paraventricular leukomalacia, bronchopulmonary dysplasia, intraventricular hemorrhage, placenta-associated syndrome as well as reduced academic performance and elevated blood pressure in adolescence [3,136,137,140-145].

In adults, DNA methylation differences in the blood of smokers versus non-smokers have been reported $[10,146]$. Maternal smoking during pregnancy may change the DNA methylation profile of neonates, as evidenced in several recent studies, and this change in methylation may mediate neonatal birthweight and immune function [13,147-149]. Stroud and colleagues found that maternal smoking during pregnancy was associated with decreased infant salivary cortisol levels in the first post-natal month, and that placental NR3C1 methylation was decreased in exposed fetuses [13]. They suggest that decreased placental methylation of the NR3C1 promoter mediates the lowered cortisol levels seen in neonates [13]. Other groups have found associations between maternal smoking in pregnancy and methylation through EWAS [147-149]. The association between maternal smoking and methylation in the offspring can be seen through adolescence, suggesting that there is the potential for long-term effects of this behavior on the child $[150,151]$. One group, Kupers and colleagues, performing an EWAS with methylation and maternal smoking was able to establish the mediating effect of three CpG sites associated with growth factor independent 1 transcription repressor (GFI1) on low birth weight, concluding that these CpGs could explain 12\%-19\% of the lowered birth weight [149]. Future studies should take a similar approach when evaluating the effects of maternal exposures on fetal and neonatal outcome.

\subsection{Alcohol}

Alcohol use during pregnancy is reported by around $15 \%$ of women and is another preventable contributor to maternal and neonatal morbidity and mortality [152]. Alcohol use during pregnancy is associated with PTB, spontaneous abortion, fetal alcohol spectrum disorder, increased risk of acute myeloblastic leukemia, and poor childhood behavior [152-155]. Kesmodel and colleagues found that prenatal alcohol exposure decreased gestational age by 3-4 days, on average, in women consuming more than 10 drinks per week, but gestational age was increased by 1-2 days in women having 1-2 drinks per week [156]. Lundsberg and colleagues also saw a protective effect of alcohol use in PTB, though this phenomenon may be due to a "lifestyle effect" where women who consume low or moderate levels of alcohol may participate in an overall healthier lifestyle [157]. In adults, alcohol use has also been shown to affect the epigenomes of recurrent users, with particular implications for dysregulation of inflammatory pathways [158,159].

Changes in methylation level of specific genes may mediate the effects of alcohol exposure on fetal outcomes, though few studies have examined this relationship. Lee and colleagues found a variety of associations between maternal alcohol consumption and cord blood methylation in the fetus [160]. In this study, serotonin transporter (SLC6A4) methylation was decreased and methyl CpG binding protein 2 (MECP2) methylation was increased in maternally exposed newborns, and as both of these genes have previously been implicated in neurodevelopment, altered methylation may contribute to negative neurocognitive outcomes in prenatally exposed children [160]. Future studies should evaluate the association between $\mathrm{CpG}$ sites associated with alcohol use in the mother and PTB to better assess potential biomarkers of PTB for use in subpopulations of women who use alcohol during pregnancy. Biomarkers of maternal alcohol use in the neonate that are predictive of future neurocognitive function 
should be developed to allow earlier intervention and diagnosis to potentially improve long-term outcomes for at risk neonates.

\section{Prenatal Stress}

Maternal stress during pregnancy is an overwhelmingly common event, with $70.2 \%$ of women reporting the occurrence a stressful life event in the year preceding the birth of their child including pregnancy-specific stress, intimate partner violence, and natural disasters [161]. The number of stressful life events was highest for women at high risk for pregnancy complications (i.e., under 25 years of age, less than a high school education, African American race, unmarried, or receiving Medicaid) [161].

Maternal stress has been associated with lower gestational age, even in cases not strictly defined as PTB. Lobel and colleagues report that maternal pregnancy specific stress was predictive of gestational age, with women who had a combination of high obstetric risk and high stress delivering, on average, nine days earlier than their low stressed/low risk counterparts [162]. They note that the association between pregnancy specific stress and gestational age was still significant after controlling for obstetric risk, but poor health behaviors may also mediate the association [162].

The effects of maternal stress can be seen through dysregulation of the hypothalamicpituitary-adrenal (HPA) axis and activation of inflammatory immune pathways [36]. Stress promotes release of corticotropin-releasing factor (CRF), which stimulates release of adrenocorticotrophin (ACTH) into circulation [163]. ACTH then stimulates the synthesis and secretion of glucocorticoids [163], which then feedback to inhibit further release of CRH and ACTH [163,164]. Cortisol binds the glucocorticoid receptor (NR3C1), which can then translocate into the nucleus to either bind glucocorticoid response elements on their target genes or interact with other transcription factors, such as NF-KB [164]. Immunosuppression via glucocorticoids has been associated with decreases in cytokine production and function, impaired leukocyte access to inflamed regions, and reduction of the inflammatory response $[165,166]$.

The levels of $\mathrm{CRH}, \mathrm{ACTH}$, cortisol, and cortisol binding protein (CBP) all increase over the course of pregnancy [167]. The placenta is also capable of synthesizing CRH to supplement CRH synthesized by the hypothalamus [168]. Increased CRH induces increased secretion of ACTH and cortisol, contributing to a positive feedback loop [5]. The neonate is protected from rising levels of cortisol by the actions of 11- $\beta$ hydroxysteroid dehydrogenase type 2 (HSD11B2), which converts cortisol into cortisone [5,169]. However, very high levels of maternal cortisol, like those seen during periods of maternal stress, may override the protective actions of this enzyme, which provides a potential link between methylation of HSD11B2 and the intrauterine environment [169].

Vidal and colleagues attempted to identify just such a biomarker by examining the relationship between perceived maternal stress, measured on the Perceived Stress Scale (PSS), and neonatal methylation at imprint regulatory regions [170]. The PSS was developed as a method of measuring an individual's perception of a stressful event based on their personal interpretation of the circumstances through 14 questions answered on a numerical gradient corresponding to experiencing a certain emotion "never" to "very often" [171]. Vidal and colleagues found one differentially methylated region in cord blood that associated with PSS: the Mesoderm Specific Transcript (MEST) DMR [170]. MEST has been associated with placental mesenchymal dysplasia, which may indicate the presence of other underlying conditions [172].

Natural disasters provide a unique perspective on stress during pregnancy because they affect women agnostically, regardless of race, socioeconomic status, and other dividing characteristics. The first example of natural disaster related stress is from Project Ice Storm, which followed up with women who were pregnant around the time of the Quebec ice storm [173]. This study examined the methylation profiles of 36 offspring willing to provide blood samples around thirteen years of age. They found $1675 \mathrm{CpG}$ sites were associated with objective maternal stress levels, though no sites were significantly associated with subjective maternal stress [173]. In this study, subjective maternal stress was measured by the Impact of Events Scale-Revised, which assesses emotional and psychological symptoms after a traumatic exposure, while objective stress was measured by a questionnaire assessing 
distinct and measurable hardships, like damage to residence [173,174]. The results of this study bolster the hypothesis that methylation changes induced before birth can still be seen into adolescence.

A second natural disaster case study highlights the effects of socioeconomic status on stress. Following Hurricane Andrew that struck Louisiana in 1992, there was a significant increase in the rate of preterm birth in affected areas, regardless of race [4]. However, PTB was increased only in African American populations living in unaffected areas after controlling for race. The authors suggest that portions of the population already experiencing high levels of stress and health disparity may be disproportionately affected by acute stress, and further research is needed to identify the epigenetic and biological pathways behind this phenomenon [4].

In addition to acute stress, chronic stress also contributes to an adverse intrauterine environment for the fetus. There has been considerable debate in the field as to the effects of chronic stress on cortisol levels [175]. However, chronic stress is more likely to produce the types of epigenetic changes that may be informative as a biomarker. One potential source of chronic stress is intimate partner violence (IPV), which is associated with adverse maternal pregnancy outcomes in pregnancy, including delivering preterm, hemorrhage, preeclampsia, vaginal bleeding, hypertension, uterine rupture, spontaneous abortion, and maternal death $[6,176]$. In a recent meta-analysis, domestic abuse was associated with both PTB and LBW [177].

The effects of intimate partner violence can be perpetuated epigenetically in the fetus, and are still evident into adolescence [178]. When examining methylation of the glucocorticoid receptor gene, Radtke and colleagues saw a significant association between methylation and maternal IPV experience during pregnancy. However, IPV preceding or following pregnancy had no effect on NR3C1 methylation of adolescents [178]. This finding supports the hypothesis that maternal stress in pregnancy influences the HPA axis in her offspring, and these effects can be seen into adolescence, and possibly beyond. Thus, the NR3C1 gene should be further investigated for associations with adverse outcomes in the fetus and later in life. A biomarker for maternal stress in pregnancy could allow identification of at risk women so that support systems to diffuse pregnancy-specific stress could be put into place [162].

\section{Support during Pregnancy}

Support during pregnancy may ameliorate some of the adverse maternal and neonates outcomes associated with maternal prenatal stress [179-182]. In an Ethiopian cohort, social support was associated with a lower likelihood of reporting depressive symptoms in pregnancy [179]. The association between depressive symptoms and support from a pregnant adolescent's mother and/or partner was also seen by Pires and colleagues in a Portuguese cohort [181]. These studies suggest that maternal support during pregnancy can reduce depressive symptoms experienced by the mother. This is significant, as depression is a risk factor for PTB, and identifying women at risk for depression during pregnancy could allow for the implementation of support systems and treatment to improve maternal quality of life and decrease the PTB rate.

Support in pregnancy can also positively influence child outcomes. Ghosh and colleagues found that partner support during pregnancy was associated with lower rates of PTB in a primarily Latina population residing in Los Angeles [180]. In this study, women under moderate to high levels of stress were at a higher risk of delivering preterm, but partner support did mediate this effect. They also note that African Americans reported the highest levels of chronic stress [180]. However, Straughen and colleagues were unable to replicate the mediating effects of social support on PTB in African Americans [182]. Giesbrecht and colleagues assessed the influence of support in pregnancy on the HPA axis of the mother through evaluating cortisol levels. They found that social support was able to mediate the effects of stress on cortisol levels, as women with effective social support showed only modest increased in cortisol in response to stress as compared to women who did not perceive their partners as supportive [183]. Therefore, support during pregnancy may protect the fetus from exposure to high cortisol levels in utero [183]. 
Several strategies for reducing stress and providing support during pregnancy have been evaluated, including yoga, massage therapy, massage therapy by a partner, and group prenatal care [184-190]. These studies have shown that the negative effects of stress during pregnancy may be mediated by certain interventions [184-187,191]. These interventions have measurable effects on levels of serotonin, dopamine, and cortisol, which could be an indicator of successful intervention [191]. Massage therapy, especially moderate pressure massage, has also shown benefits for the newborn, as assessed by their performance measured on the Brazelton Neonatal Behavioral Assessment [186,191]. Group prenatal care revolves around a model in which pregnant women engage in a small group with other women due at the same time, and with their provider at prenatal visits. This model has been shown to increase gestational length and birth weight, though reports of these benefits have been inconsistent [188-190]. Group prenatal care has also been shown to have significant benefits for maternal psychosocial outcomes, including reducing pregnancy-specific distress and post-partum depression, in women with low social support [192]. Combinations of multiple support systems could show greater benefits. To our knowledge, previous studies have not examined the effects of these interventions on the methylomes of either mother or child. Massage therapy by a partner is a cost-effective intervention for maternal stress, and its effects on biological indicators of maternal and neonatal health should be examined.

\section{Health Disparities}

African Americans experience PTB at a rate nearly 1.5-fold that of Caucasians [18]. Differences in known risk factors, such as socioeconomic status, fail to explain this disparity $[193,194]$. The excess risk in African Americans may be due to a number of underlying factors including increased activation of inflammatory pathways, exposure to stress, poor nutritional status, and an increased rate of reproductive tract infections [21,195-197]. They may also disproportionately experience health-related ramifications in response to stressful life events, as illustrated by the study of Hurricane Andrew in which only African American women had higher rates of preterm delivery [4]. Genetic and epigenetic factors have also been proposed to explain the disproportionate PTB risk among African Americans. Candidate gene studies have identified polymorphisms associated with PTB in African American cohorts, but many have failed to replicate and do not explain a significant proportion of the racial disparity $[31,198]$. Two recent studies have identified race-specific methylation differences that are identifiable at birth $[135,199]$. Still, indicators of socioeconomic status are also evident at birth, as Tehranifar and colleagues found that low socioeconomic status associated with higher methylation of a repetitive element, Sat2 [200]. Another study found gene-specific differences in stress-response pathways related to early life socioeconomic status [201]. It is likely that each of these factors increases risk for PTB incrementally without explaining a substantial proportion of the variance on its own.

\section{Maternal Weathering}

The maternal weathering hypothesis, first proposed by Geronimus, postulates that the growing disparity with maternal age in pregnancy complications may be reflective of accelerated aging due to disproportionately experienced stressors [202-204]. Stress may cause accelerated aging through oxidative stress, telomere shortening, or acceleration of the "epigenetic clock", discussed below [205-207]. In this context, accelerated aging refers to an increase in cellular age over chronological age. This hypothesis has been supported through the demonstration of a divergence in risk for PTB between African American and Caucasian cohorts that were otherwise comparable [204]. Thus, age acceleration may be associated with pregnancy complications in women with disproportionately higher levels of stress.

The original weathering hypothesis was focused on differences in pregnancy complication rates between African Americans and Caucasians, though it has recently been tested in Mexican-American and Caucasian populations. However, there is little evidence for weathering in these populations, suggesting that wreathing may be specific to African Americans and not generalizable to members of 
other racial groups with low socioeconomic status [204,208-210]. Further examination of accelerated aging is required to better understand its potential contributions to preterm birth.

\section{Accelerated Aging}

\subsection{Telomere Length and Cellular Senescence}

Accelerated aging, as measured through telomere length, has recently been interrogated for associations with PTB [211-214]. Telomeres cap the ends of chromosomes to promote chromosomal stability and aid in replication. The length of telomeres, a hallmark of aging, is regulated by the enzyme telomerase, which adds additional nucleotides to the chromosome ends to help correct for telomere shortening that occurs with each cell division $[215,216]$. Previous studies have shown that telomere length associates with PTB, pPROM, still birth, preeclampsia, and intrauterine growth restriction, though the mechanisms driving these associations remain to be elucidated [211,212,217-219]. Menon and colleagues reported an inverse relationship between cord blood leukocyte telomere length and gestational age, noting that leukocytes from neonates born preterm had longer telomeres than leukocytes form neonates born either at term or with PPROM [212]. This finding is in contrast with Friedrich and colleagues, who reported no difference between telomere length in cord blood leukocytes of term and preterm neonates, although they did see a difference in telomere length between very low birth weight preterm neonates and low birth weight preterm neonates [213]. This discrepancy may be due to differences in the way telomere length was measured in these the two studies. Friedrich and colleagues also reported a decrease in telomere length between 27 and 32 weeks gestation, consistent with the findings from Menon and colleagues, but did not see an association with telomere length after 33 weeks [213]. Menon and colleagues also saw a strong correlation between telomere length in leukocytes and placenta, though placental telomeres were longer than those of leukocytes on average [212].

In a more recent study, Ferrari, Menon, and colleagues examined telomere length in placentas from 42 stillbirths, 43 term, and 15 preterm live births. They found that, overall, placental telomere length was two-fold shorter in placentas from stillbirths. Interestingly, they also note that telomere length in pPROM was similar to telomere length in stillbirths. These results suggest that premature senescence and placental accelerated aging are associated with the severe negative outcomes of stillbirth and pPROM [211]. Both of these studies, in addition to the findings of Biron-Shental and colleagues, which suggests that pre-eclampsia and intrauterine growth restriction are associated with shorter telomeres, imply that telomere length may be used as a proxy for cellular aging and senescence [211,212,219].

Consistent with the hypothesis that telomere length associates with cellular aging and senescence, shortened telomeres have been associated with a variety of negative health outcomes including cancer, dementia, stroke, type II diabetes, myocardial infarction, psychiatric disorders, and mortality, though direct causal relationships have not been established [220-225]. Therefore, beginning life with shorter telomere length may predispose a neonate to long-term health consequences. These results are consistent with a study by Shalev and colleagues that found perinatal complications associated with shorter telomeres and older perceived facial age at age 38 [226].

In addition to associations with pregnancy complications and overall health, the impact of maternal stress on telomere length in neonates has been studied. Entringer and colleagues examined telomere length in adult subjects exposed to maternal stress during pregnancy and found that stress exposure associated with shorter telomere length in adults, and this effect was more pronounced in female offspring exposed to stress [227]. Although this study did not examine the direct relationship between telomere length at birth and maternal stress, a more recent study by Entringer and colleagues found that pregnancy-specific stress did associate with newborn telomere length in a cohort of 27 mothers and neonates [228]. Due to these vast associations between telomere length, PTB, pregnancy complications and general poor health, telomere length is attractive as potential biomarker of future neonatal development. 


\subsection{Epigenetic Clock}

Recently, DNA methylation of a select group of CpG sites has been used to generate a promising new biomarker related to aging. It is widely accepted that aging influences DNA methylation across the genome, and several recent studies have taken advantage of age-related methylation changes to build a predictor of DNA methylation age (DNAm age) [229-231]. A DNAm age that is higher than a person's chronological age may indicate accelerated aging, which is a potential metric of stress, as evidenced by recent studies of DNAm age in developmental and neurocognitive outcomes, as well as all-cause mortality [207,232]. Measuring DNAm age has potential for use in predicting maternal risk during pregnancy, though this relationship has not yet been examined. One study has examined the relationship between accelerated age and a range of phenotypes in a large, longitudinal cohort. Overall, they found that DNAm age became more correlated as the child aged, suggesting that this predictor may not work well for neonates and young children. Accelerated age measured at birth associated with Caesarian-section and maternal smoking $(p<0.05)$, though accelerated age measured in childhood and/or adolescence associated with birthweight and maternal characteristics measured during pregnancy including selenium exposure and BMI [233].

Placental and cord blood samples were included when the DNAm age predictor was initially developed, but the age of all of these samples was set to 0. Due to this, DNAm age, as initially operationalized, is not accurate enough to discriminate weeks of gestation. Gestational age has previously been associated with changes in methylation at various CpG sites [11,42,234,235], which could be used to develop a predictor accurate for neonates. Further studies on DNA methylation in neonatal cord blood are required for the development of a neonatal age predictor.

\section{Conclusions and Recommendations}

Figure 2 summarizes the process of identifying an epigenetic biomarker and underscores the complexity of developing one for PTB or its risk factors. While the clinical need is clear, an epigenetic biomarker for PTB would substantially improve our ability to identify and treat women at the highest risk for delivering preterm. Targeted interventions could reduce multiple health burdens associated with delivering preterm and being born preterm. Such a biomarker does not yet exist, in part due to the complexity of the intrauterine environment and the heterogeneity within the clinical definition of PTB. Gene regulation varies over the course of pregnancy and that regulation is likely influenced by a number of independent environmental factors. Thus, potential biomarkers would need to be capable of distinguishing health outcomes within diverse nutritional or psychosocial contexts. Studies that simultaneously evaluate multiple risk factors for PTB will have the most potential to identify epigenetic predictors of PTB that can be developed into biomarkers. Similarly, biomarkers should perform equally well across different ancestries and socioeconomic statuses, as recent studies have identified methylation differences in ancestry and SES that are evident at birth $[135,199,200]$. Recent studies have made substantial progress towards identifying and replicating epigenetic associations in diverse cohorts, and it is important that basic and epidemiological researchers develop partnerships though which the most promising results from their work can be extended into prospective and clinical studies.

In this review, we have outlined current progress on biomarker development and the need for additional epigenetic studies of PTB. In addition to individual CpG sites, summary measures that integrate information from multiple regions of the genome may also be informative. The use of the DNAm age predictor to evaluate future health risk in adults demonstrates that this type of epigenetic predictor, which combines several hundred CpG sites, may be useful for predicting perinatal development, if modified for use in neonates. Once appropriate biomarkers are identified, targeted and cost-effective assays could be developed to prospectively screen for PTB. Prospective screening is an essential stage in development of biomarkers for the assessment of whether statistical associations between PTB and DNA methylation will have clinical utility and be useful for accurate and rapid prediction of PTB. Successful development and clinical implementation of such a biomarker would aid 
in reducing the substantial health burden of PTB and has the potential to improve both maternal and offspring health.

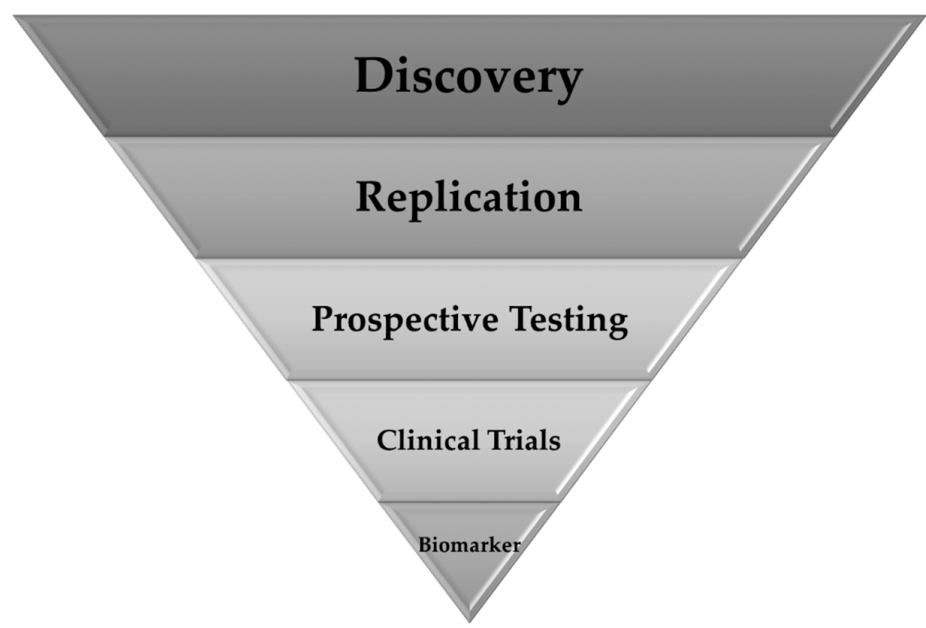

Figure 2. Phases of biomarker development. The width of each phase is analogous to the number of studies anticipated.

Acknowledgments: The authors would like to thank Samantha Resin for her editorial assistance. This work was supported by a grant from the National Institutes of Minority and Health Disparities (MD009064). Salary support for AKK was provided, in part, by the National Institute of General Medical Sciences (T32GM008490).

Author Contributions: Anna K. Knight drafted and edited the review. Alicia K. Smith contributed to the draft and made substantial revisions.

Conflicts of Interest: The authors declare no conflict of interest.

\section{Abbreviations}

The following abbreviations are used in this manuscript:

$\begin{array}{ll}\text { 25-OHD } & \text { 1,25-dihydroxyvitamin D } \\ \text { ACTH } & \text { adrenocorticotrophin } \\ \text { AED } & \text { Antiepileptic drugs } \\ \text { BMI } & \text { Body Mass Index } \\ \text { CBP } & \text { Cortisol binding protein } \\ \text { CpG } & \text { Cytosine Guanine dinucleotide } \\ \text { CRH } & \text { Corticotrophin-releasing hormone } \\ \text { DMR } & \text { Differentially methylated region } \\ \text { DNAm age } & \text { DNA methylation age } \\ \text { EWAS } & \text { Epigenome-wide association study } \\ \text { GFI1 } & \text { Growth factor independent 1 transcription repressor } \\ \text { HPA axis } & \text { Hypothalamic-pituitary-adrenal axis } \\ \text { HSD11B2 } & \text { Hydroxysteroid dehydrogenase type 2 } \\ \text { IGF2 } & \text { Insulin-like growth factor 2 } \\ \text { IPV } & \text { Intimate partner violence } \\ \text { LBW } & \text { Low birth weight } \\ \text { MECP2 } & \text { Methyl CpG binding protein 2 } \\ \text { MEST } & \text { Mesoderm Specific Transcript } \\ \text { miRNA } & \text { microRNA } \\ \text { NR3C1 } & \text { Glucocorticoid receptor } \\ \text { PEG3 } & \text { Paternally Expressed 3 }\end{array}$




$\begin{array}{ll}\text { pPROM } & \text { Preterm, premature rupture of membranes } \\ \text { PSS } & \text { Perceived stress scale } \\ \text { PTB } & \text { Preterm birth } \\ \text { RAR } & \text { Retinoic acid receptor } \\ \text { SES } & \text { Socioeconomic status } \\ \text { VDBP } & \text { Vitamin D Binding Protein } \\ \text { VDR } & \text { Vitamin D Receptor } \\ \text { VTRNA2-1 } & \text { Vault RNA 2-1 }\end{array}$

\section{References}

1. World Health Organization. WHO Recommendations on Interventions to Improve Preterm Birth Outcomes; WHO: Geneva, Switzerland, 2015.

2. Alhusen, J.L.; Ray, E.; Sharps, P.; Bullock, L. Intimate partner violence during pregnancy: Maternal and neonatal outcomes. J. Women's Health 2015, 24, 100-106. [CrossRef] [PubMed]

3. Aliyu, M.H.; Lynch, O.; Wilson, R.E.; Alio, A.P.; Kristensen, S.; Marty, P.J.; Whiteman, V.E.; Salihu, H.M. Association between tobacco use in pregnancy and placenta-associated syndromes: A population-based study. Arch. Gynecol. Obstet. 2011, 283, 729-734. [CrossRef] [PubMed]

4. Antipova, A.; Curtis, A. The post-disaster negative health legacy: Pregnancy outcomes in louisiana after hurricane andrew. Disasters 2015, 39, 665-686. [CrossRef] [PubMed]

5. Duthie, L.; Reynolds, R.M. Changes in the maternal hypothalamic-pituitary-adrenal axis in pregnancy and postpartum: Influences on maternal and fetal outcomes. Neuroendocrinology 2013, 98, 106-115. [CrossRef] [PubMed]

6. El Kady, D.; Gilbert, W.M.; Xing, G.; Smith, L.H. Maternal and neonatal outcomes of assaults during pregnancy. Obstet. Gynecol. 2005, 105, 357-363. [CrossRef] [PubMed]

7. Emes, R.D.; Clifford, H.; Haworth, K.E.; Farrell, W.E.; Fryer, A.A.; Carroll, W.D.; Ismail, K.M. Antiepileptic drugs and the fetal epigenome. Epilepsia 2013, 54, e16-e19. [CrossRef] [PubMed]

8. Smith, A.K.; Conneely, K.N.; Newport, D.J.; Kilaru, V.; Schroeder, J.W.; Pennell, P.B.; Knight, B.T.; Cubells, J.C.; Stowe, Z.N.; Brennan, P.A. Prenatal antiepileptic exposure associates with neonatal DNA methylation differences. Epigenetics Off. J. DNA Methylation Soc. 2012, 7, 458-463. [CrossRef] [PubMed]

9. Sharp, G.C.; Lawlor, D.A.; Richmond, R.C.; Fraser, A.; Simpkin, A.; Suderman, M.; Shihab, H.A.; Lyttleton, O.; McArdle, W.; Ring, S.M.; et al. Maternal pre-pregnancy bmi and gestational weight gain, offspring DNA methylation and later offspring adiposity: Findings from the avon longitudinal study of parents and children. Int. J. Epidemiol. 2015, 44, 1288-1304. [PubMed]

10. Shenker, N.S.; Polidoro, S.; van Veldhoven, K.; Sacerdote, C.; Ricceri, F.; Birrell, M.A.; Belvisi, M.G.; Brown, R.; Vineis, P.; Flanagan, J.M. Epigenome-wide association study in the european prospective investigation into cancer and nutrition (epic-turin) identifies novel genetic loci associated with smoking. Hum. Mol. Genet. 2013, 22, 843-851. [CrossRef] [PubMed]

11. Simpkin, A.J.; Suderman, M.; Gaunt, T.R.; Lyttleton, O.; McArdle, W.L.; Ring, S.M.; Tilling, K.; Smith, G.D.; Relton, C.L. Longitudinal analysis of DNA methylation associated with birth weight and gestational age. Hum. Mol. Genet. 2015, 24, 3752-3763. [CrossRef] [PubMed]

12. Soubry, A.; Murphy, S.; Huang, Z.; Murtha, A.; Schildkraut, J.; Jirtle, R.; Wang, F.; Kurtzberg, J.; Demark-Wahnefried, W.; Forman, M.; et al. The effects of depression and use of antidepressive medicines during pregnancy on the methylation status of the IGF2 imprinted control regions in the offspring. Clin. Epigenetics 2011. [CrossRef]

13. Stroud, L.R.; Papandonatos, G.D.; Rodriguez, D.; McCallum, M.; Salisbury, A.L.; Phipps, M.G.; Lester, B.; Huestis, M.A.; Niaura, R.; Padbury, J.F.; et al. Maternal smoking during pregnancy and infant stress response: Test of a prenatal programming hypothesis. Psychoneuroendocrinology 2014, 48, 29-40. [PubMed]

14. Colburn, W.A.; DeGruttola, V.G.; DeMets, D.L.; Downing, G.J.; Hoth, D.F.; Oates, J.A.; Peck, C.C.; Schooley, R.T.; Spilker, B.A.; Woodcock, J.; et al. Biomarkers and surrogate endpoints: Preferred definitions and conceptual framework. Clin. Pharmacol. Ther. 2001, 69, 89-95.

15. Holsboer, F. How can we realize the promise of personalized antidepressant medicines? Nat. Rev. Neurosci. 2008, 9, 638-646. [CrossRef] [PubMed] 
16. Peedicayil, J. Epigenetic biomarkers in psychiatric disorders. Br. J. Pharmacol. 2008, 155, 795-796. [CrossRef] [PubMed]

17. Alliance, N.B.D. Biomarker Validation. Available online: http://nbdabiomarkers.org/about/what-we-do/ pipeline-overview/biomarker-validation (accessed on 12 February 2016).

18. Hamilton, B.E.; Martin, J.A.; Ventura, S.J. Births: Preliminary data for 2011. Natl. Vital Stat. Rep. 2012, 61, 1-20. [PubMed]

19. Callaghan, W.M.; MacDorman, M.F.; Rasmussen, S.A.; Qin, C.; Lackritz, E.M. The contribution of preterm birth to infant mortality rates in the united states. Pediatrics 2006, 118, 1566-1573. [CrossRef] [PubMed]

20. Beck, S.; Wojdyla, D.; Say, L.; Betran, A.P.; Merialdi, M.; Requejo, J.H.; Rubens, C.; Menon, R.; van Look, P.F. The worldwide incidence of preterm birth: A systematic review of maternal mortality and morbidity. Bull. World Health Organ. 2010, 88, 31-38. [CrossRef] [PubMed]

21. Behrman, R.E.; Butler, A.S. Preterm Birth: Causes, Consequences, and Prevention; The National Academies Press: Washington, DC, USA, 2007; p. 792.

22. Yuan, W.; Basso, O.; Sorensen, H.T.; Olsen, J. Indicators of fetal growth and infectious disease in childhood-A birth cohort with hospitalization as outcome. Eur. J. Epidemiol. 2001, 17, 829-834. [CrossRef] [PubMed]

23. Bhutta, A.T.; Cleves, M.A.; Casey, P.H.; Cradock, M.M.; Anand, K.J. Cognitive and behavioral outcomes of school-aged children who were born preterm: A meta-analysis. JAMA 2002, 288, 728-737. [CrossRef] [PubMed]

24. Burdge, G.C.; Hanson, M.A.; Slater-Jefferies, J.L.; Lillycrop, K.A. Epigenetic regulation of transcription: A mechanism for inducing variations in phenotype (fetal programming) by differences in nutrition during early life? Br. J. Nutr. 2007, 97, 1036-1046. [CrossRef] [PubMed]

25. Kajantie, E.; Osmond, C.; Barker, D.J.; Eriksson, J.G. Preterm birth-A risk factor for type 2 diabetes? The helsinki birth cohort study. Diabetes Care 2010, 33, 2623-2625. [PubMed]

26. Kessous, R.; Shoham-Vardi, I.; Pariente, G.; Holcberg, G.; Sheiner, E. An association between preterm delivery and long-term maternal cardiovascular morbidity. Am. J. Obstet. Gynecol. 2013. [CrossRef]

27. James-Todd, T.; Wise, L.; Boggs, D.; Rich-Edwards, J.; Rosenberg, L.; Palmer, J. Preterm birth and subsequent risk of type 2 diabetes in black women. Epidemiology 2014, 25, 805-810. [CrossRef] [PubMed]

28. Melbye, M.; Wohlfahrt, J.; Andersen, A.M.; Westergaard, T.; Andersen, P.K. Preterm delivery and risk of breast cancer. Br. J. Cancer 1999, 80, 609-613. [CrossRef] [PubMed]

29. Lykke, J.A.; Paidas, M.J.; Damm, P.; Triche, E.W.; Kuczynski, E.; Langhoff-Roos, J. Preterm delivery and risk of subsequent cardiovascular morbidity and type-ii diabetes in the mother. BJOG 2010, 117, $274-281$. [CrossRef] [PubMed]

30. Goldenberg, R.L.; Culhane, J.F.; Iams, J.D.; Romero, R. Epidemiology and causes of preterm birth. Lancet 2008, 371, 75-84. [CrossRef]

31. Parets, S.E.; Knight, A.K.; Smith, A.K. Insights into genetic susceptibility in the etiology of spontaneous preterm birth. Appl. Clin. Genet. 2015, 8, 283-290. [PubMed]

32. Moutquin, J.M. Classification and heterogeneity of preterm birth. BJOG 2003, 110, 30-33. [CrossRef]

33. Ananth, C.V.; Vintzileos, A.M. Epidemiology of preterm birth and its clinical subtypes. J. Matern.-Fetal Neonatal Med. 2006, 19, 773-782. [CrossRef] [PubMed]

34. Gimenez, L.G.; Krupitzki, H.B.; Momany, A.M.; Gili, J.A.; Poletta, F.A.; Campana, H.; Cosentino, V.R.; Saleme, C.; Pawluk, M.; Murray, J.C.; et al. Maternal and neonatal epidemiological features in clinical subtypes of preterm birth. J. Matern.-Fetal Neonatal Med. 2015, 15, 1-9.

35. Liu, Y.; Hoyo, C.; Murphy, S.; Huang, Z.; Overcash, F.; Thompson, J.; Brown, H.; Murtha, A.P. DNA methylation at imprint regulatory regions in preterm birth and infection. Am. J. Obstet. Gynecol. 2013. [CrossRef] [PubMed]

36. Parets, S.E.; Bedient, C.E.; Menon, R.; Smith, A.K. Preterm birth and its long-term effects: Methylation to mechanisms. Biology 2014, 3, 498-513. [CrossRef] [PubMed]

37. Voltolini, C.; Torricelli, M.; Conti, N.; Vellucci, F.L.; Severi, F.M.; Petraglia, F. Understanding spontaneous preterm birth: From underlying mechanisms to predictive and preventive interventions. Reprod. Sci. 2013, 20, 1274-1292. [CrossRef] [PubMed]

38. Parizek, A.; Koucky, M.; Duskova, M. Progesterone, inflammation and preterm labor. J. Steroid Biochem. Mol. Biol. 2014, 139, 159-165. [CrossRef] [PubMed] 
39. Blencowe, H.; Cousens, S.; Chou, D.; Oestergaard, M.; Say, L.; Moller, A.B.; Kinney, M.; Lawn, J. Born too soon: The global epidemiology of 15 million preterm births. Reprod. Health 2013. [CrossRef] [PubMed]

40. Bonasio, R.; Tu, S.; Reinberg, D. Molecular signals of epigenetic states. Science 2010, 330, 612-616. [CrossRef] [PubMed]

41. Maunakea, A.K.; Nagarajan, R.P.; Bilenky, M.; Ballinger, T.J.; D’Souza, C.; Fouse, S.D.; Johnson, B.E.; Hong, C.; Nielsen, C.; Zhao, Y.; et al. Conserved role of intragenic DNA methylation in regulating alternative promoters. Nature 2010, 466, 253-257. [PubMed]

42. Parets, S.E.; Conneely, K.N.; Kilaru, V.; Fortunato, S.J.; Syed, T.A.; Saade, G.; Smith, A.K.; Menon, R. Fetal DNA methylation associates with early spontaneous preterm birth and gestational age. PLoS ONE 2013,8, e67489. [CrossRef] [PubMed]

43. Cruickshank, M.N.; Oshlack, A.; Theda, C.; Davis, P.G.; Martino, D.; Sheehan, P.; Dai, Y.; Saffery, R.; Doyle, L.W.; Craig, J.M. Analysis of epigenetic changes in survivors of preterm birth reveals the effect of gestational age and evidence for a long term legacy. Genome Med. 2013, 5, 96. [CrossRef] [PubMed]

44. Fernando, F.; Keijser, R.; Henneman, P.; van der Kevie, A.M.F.; Mannens, M.M.; van der Post, J.A.; Afink, G.B.; Ris-Stalpers, C. The idiopathic preterm delivery methylation profile in umbilical cord blood DNA. BMC Genom. 2015. [CrossRef] [PubMed]

45. Parets, S.E.; Conneely, K.N.; Kilaru, V.; Menon, R.; Smith, A.K. DNA methylation provides insight into intergenerational risk for preterm birth in african americans. Epigenetics Off. J. DNA Methylation Soc. 2015, 10, 784-792. [CrossRef] [PubMed]

46. Heng, Y.J.; Pennell, C.E.; Chua, H.N.; Perkins, J.E.; Lye, S.J. Whole blood gene expression profile associated with spontaneous preterm birth in women with threatened preterm labor. PLoS ONE 2014, 9, e96901. [CrossRef] [PubMed]

47. Menon, R.; Bhat, G.; Saade, G.R.; Spratt, H. Multivariate adaptive regression splines analysis to predict biomarkers of spontaneous preterm birth. Acta Obstet. Gynecol. Scand. 2014, 93, 382-391. [CrossRef] [PubMed]

48. Jelliffe-Pawlowski, L.L.; Baer, R.J.; Blumenfeld, Y.J.; Ryckman, K.K.; O’Brodovich, H.M.; Gould, J.B.; Druzin, M.L.; El-Sayed, Y.Y.; Lyell, D.J.; Stevenson, D.K.; et al. Maternal characteristics and mid-pregnancy serum biomarkers as risk factors for subtypes of preterm birth. BJOG 2015, 122, 1484-1493. [PubMed]

49. Wallenstein, M.B.; Jelliffe-Pawlowski, L.L.; Yang, W.; Carmichael, S.L.; Stevenson, D.K.; Ryckman, K.K.; Shaw, G.M. Inflammatory biomarkers and spontaneous preterm birth among obese women. J. Matern.-Fetal Neonatal Med. 2015, 18, 1-6. [CrossRef] [PubMed]

50. Jelliffe-Pawlowski, L.L.; Ryckman, K.K.; Bedell, B.; O’Brodovich, H.M.; Gould, J.B.; Lyell, D.J.; Borowski, K.S.; Shaw, G.M.; Murray, J.C.; Stevenson, D.K. Combined elevated midpregnancy tumor necrosis factor alpha and hyperlipidemia in pregnancies resulting in early preterm birth. Am. J. Obstet. Gynecol. 2014. [CrossRef] [PubMed]

51. Smith, G.C.; Shah, I.; White, I.R.; Pell, J.P.; Crossley, J.A.; Dobbie, R. Maternal and biochemical predictors of spontaneous preterm birth among nulliparous women: A systematic analysis in relation to the degree of prematurity. Int. J. Epidemiol. 2006, 35, 1169-1177. [CrossRef] [PubMed]

52. Tancrede, S.; Bujold, E.; Giguere, Y.; Renald, M.H.; Girouard, J.; Forest, J.C. Mid-trimester maternal serum afp and hcg as markers of preterm and term adverse pregnancy outcomes. J. Obstet. Gynaecol. Can. 2015, 37, 111-116. [CrossRef]

53. Yuan, W.; Chen, L.; Bernal, A.L. Is elevated maternal serum alpha-fetoprotein in the second trimester of pregnancy associated with increased preterm birth risk? A systematic review and meta-analysis. Eur. J. Obstet. Gynecol. Reprod. Biol. 2009, 145, 57-64. [CrossRef] [PubMed]

54. Menon, R.; Conneely, K.N.; Smith, A.K. DNA methylation: An epigenetic risk factor in preterm birth. Reprod. Sci. 2012, 19, 6-13. [CrossRef] [PubMed]

55. Tendl, K.A.; Schulz, S.M.; Mechtler, T.P.; Bohn, A.; Metz, T.; Greber-Platzer, S.; Kasper, D.C.; Herkner, K.R.; Item, C.B. DNA methylation pattern of calca in preterm neonates with bacterial sepsis as a putative epigenetic biomarker. Epigenetics Off. J. DNA Methylation Soc. 2013, 8, 1261-1267. [CrossRef] [PubMed]

56. Anderson, C.M.; Ralph, J.L.; Wright, M.L.; Linggi, B.; Ohm, J.E. DNA methylation as a biomarker for preeclampsia. Biol. Res. Nurs. 2014, 16, 409-420. [CrossRef] [PubMed]

57. Barker, D.J. The origins of the developmental origins theory. J. Intern. Med. 2007, 261, 412-417. [CrossRef] [PubMed] 
58. Ravelli, G.P.; Stein, Z.A.; Susser, M.W. Obesity in young men after famine exposure in utero and early infancy. N. Engl. J. Med. 1976, 295, 349-353. [CrossRef] [PubMed]

59. Hoek, H.W.; Brown, A.S.; Susser, E. The dutch famine and schizophrenia spectrum disorders. Soc. Psychiatry Psychiatr. Epidemiol. 1998, 33, 373-379. [CrossRef] [PubMed]

60. de Rooij, S.R.; Painter, R.C.; Phillips, D.I.; Osmond, C.; Michels, R.P.; Godsland, I.F.; Bossuyt, P.M.; Bleker, O.P.; Roseboom, T.J. Impaired insulin secretion after prenatal exposure to the dutch famine. Diabetes Care 2006, 29, 1897-1901. [CrossRef] [PubMed]

61. Yarde, F.; Broekmans, F.J.; van der Pal-de Bruin, K.M.; Schonbeck, Y.; te Velde, E.R.; Stein, A.D.; Lumey, L.H. Prenatal famine, birthweight, reproductive performance and age at menopause: The dutch hunger winter families study. Hum. Reprod. 2013, 28, 3328-3336. [CrossRef] [PubMed]

62. Franzek, E.J.; Sprangers, N.; Janssens, A.C.; Van Duijn, C.M.; Van De Wetering, B.J. Prenatal exposure to the 1944-45 dutch "hunger winter" and addiction later in life. Addiction 2008, 103, 433-438. [CrossRef] [PubMed]

63. Wadhwa, P.D.; Buss, C.; Entringer, S.; Swanson, J.M. Developmental origins of health and disease: Brief history of the approach and current focus on epigenetic mechanisms. Semin. Reprod. Med. 2009, 27, 358-368. [CrossRef] [PubMed]

64. Tobi, E.W.; Lumey, L.H.; Talens, R.P.; Kremer, D.; Putter, H.; Stein, A.D.; Slagboom, P.E.; Heijmans, B.T. DNA methylation differences after exposure to prenatal famine are common and timing- and sex-specific. Hum. Mol. Genet. 2009, 18, 4046-4053. [CrossRef] [PubMed]

65. Murphy, S.K.; Huang, Z.; Hoyo, C. Differentially methylated regions of imprinted genes in prenatal, perinatal and postnatal human tissues. PLoS ONE 2012, 7, e40924. [CrossRef] [PubMed]

66. Silver, M.J.; Kessler, N.J.; Hennig, B.J.; Dominguez-Salas, P.; Laritsky, E.; Baker, M.S.; Coarfa, C.; Hernandez-Vargas, H.; Castelino, J.M.; Routledge, M.N.; et al. Independent genomewide screens identify the tumor suppressor vtrna2-1 as a human epiallele responsive to periconceptional environment. Genome Biol. 2015. [CrossRef]

67. Salihu, H.M.; Mbah, A.K.; Alio, A.P.; Clayton, H.B.; Lynch, O. Low pre-pregnancy body mass index and risk of medically indicated versus spontaneous preterm singleton birth. Eur. J. Obstet. Gynecol. Reprod. Biol. 2009, 144, 119-123. [CrossRef] [PubMed]

68. Hendler, I.; Goldenberg, R.L.; Mercer, B.M.; Iams, J.D.; Meis, P.J.; Moawad, A.H.; MacPherson, C.A.; Caritis, S.N.; Miodovnik, M.; Menard, K.M.; et al. The preterm prediction study: Association between maternal body mass index and spontaneous and indicated preterm birth. Am. J. Obstet. Gynecol. 2005, 192, 882-886. [PubMed]

69. Doherty, D.A.; Magann, E.F.; Francis, J.; Morrison, J.C.; Newnham, J.P. Pre-pregnancy body mass index and pregnancy outcomes. Int. J. Gynaecol. Obstet. 2006, 95, 242-247. [CrossRef] [PubMed]

70. Hayward, C.E.; Higgins, L.; Cowley, E.J.; Greenwood, S.L.; Mills, T.A.; Sibley, C.P.; Wareing, M. Chorionic plate arterial function is altered in maternal obesity. Placenta 2013, 34, 281-287. [CrossRef] [PubMed]

71. Luiza, J.W.; Gallaher, M.J.; Powers, R.W. Urinary cortisol and depression in early pregnancy: Role of adiposity and race. BMC Pregnancy Childbirth 2015. [CrossRef] [PubMed]

72. Madan, J.C.; Davis, J.M.; Craig, W.Y.; Collins, M.; Allan, W.; Quinn, R.; Dammann, O. Maternal obesity and markers of inflammation in pregnancy. Cytokine 2009, 47, 61-64. [CrossRef] [PubMed]

73. Meenakshi; Srivastava, R.; Sharma, N.R.; Kushwaha, K.P.; Aditya, V. Obstetric behavior and pregnancy outcome in overweight and obese women: Maternal and fetal complications and risks in relation to maternal overweight and obesity. J. Obstet. Gynaecol. India 2012, 62, 276-280. [CrossRef] [PubMed]

74. Ovesen, P.; Rasmussen, S.; Kesmodel, U. Effect of prepregnancy maternal overweight and obesity on pregnancy outcome. Obstet. Gynecol. 2011, 118, 305-312. [CrossRef] [PubMed]

75. Persson, M.; Johansson, S.; Villamor, E.; Cnattingius, S. Maternal overweight and obesity and risks of severe birth-asphyxia-related complications in term infants: A population-based cohort study in sweden. PLoS Med. 2014, 11, e1001648. [CrossRef] [PubMed]

76. Crisham Janik, M.D.; Newman, T.B.; Cheng, Y.W.; Xing, G.; Gilbert, W.M.; Wu, Y.W. Maternal diagnosis of obesity and risk of cerebral palsy in the child. J. Pediatr. 2013, 163, 1307-1312. [CrossRef] [PubMed]

77. Oteng-Ntim, E.; Kopeika, J.; Seed, P.; Wandiembe, S.; Doyle, P. Impact of obesity on pregnancy outcome in different ethnic groups: Calculating population attributable fractions. PLoS ONE 2013, 8, e53749. 
78. Nomura, Y.; Lambertini, L.; Rialdi, A.; Lee, M.; Mystal, E.Y.; Grabie, M.; Manaster, I.; Huynh, N.; Finik, J.; Davey, M.; et al. Global methylation in the placenta and umbilical cord blood from pregnancies with maternal gestational diabetes, preeclampsia, and obesity. Reprod. Sci. 2014, 21, 131-137. [PubMed]

79. Michels, K.B.; Harris, H.R.; Barault, L. Birthweight, maternal weight trajectories and global DNA methylation of line-1 repetitive elements. PLoS ONE 2011, 6, e25254. [CrossRef] [PubMed]

80. Liu, X.; Chen, Q.; Tsai, H.J.; Wang, G.; Hong, X.; Zhou, Y.; Zhang, C.; Liu, C.; Liu, R.; Wang, H.; et al. Maternal preconception body mass index and offspring cord blood DNA methylation: Exploration of early life origins of disease. Environ. Mol. Mutagen. 2014, 55, 223-230. [PubMed]

81. Jasoni, C.L.; Sanders, T.R.; Kim, D.W. Do all roads lead to rome? The role of neuro-immune interactions before birth in the programming of offspring obesity. Front. Neurosci. 2014. [CrossRef]

82. Kim, D.W.; Young, S.L.; Grattan, D.R.; Jasoni, C.L. Obesity during pregnancy disrupts placental morphology, cell proliferation, and inflammation in a sex-specific manner across gestation in the mouse. Biol. Reprod. 2014. [CrossRef] [PubMed]

83. Parker, V.J.; Solano, M.E.; Arck, P.C.; Douglas, A.J. Diet-induced obesity may affect the uterine immune environment in early-mid pregnancy, reducing nk-cell activity and potentially compromising uterine vascularization. Int. J. Obes. 2014, 38, 766-774. [CrossRef] [PubMed]

84. Sen, S.; Iyer, C.; Klebenov, D.; Histed, A.; Aviles, J.A.; Meydani, S.N. Obesity impairs cell-mediated immunity during the second trimester of pregnancy. Am. J. Obstet. Gynecol. 2013. [CrossRef] [PubMed]

85. Puzziferri, N.; Roshek, T.B., 3rd; Mayo, H.G.; Gallagher, R.; Belle, S.H.; Livingston, E.H. Long-term follow-up after bariatric surgery: A systematic review. JAMA 2014, 312, 934-942.

86. Guenard, F.; Deshaies, Y.; Cianflone, K.; Kral, J.G.; Marceau, P.; Vohl, M.C. Differential methylation in glucoregulatory genes of offspring born before vs. After maternal gastrointestinal bypass surgery. Proc. Natl. Acad. Sci. USA 2013, 110, 11439-11444. [CrossRef] [PubMed]

87. Bramham, K.; Parnell, B.; Nelson-Piercy, C.; Seed, P.T.; Poston, L.; Chappell, L.C. Chronic hypertension and pregnancy outcomes: Systematic review and meta-analysis. BMJ 2014. [CrossRef] [PubMed]

88. Barbour, L.A. Changing perspectives in pre-existing diabetes and obesity in pregnancy: Maternal and infant short- and long-term outcomes. Curr. Opin. Endocrinol. Diabetes Obes. 2014, 21, 257-263. [CrossRef] [PubMed]

89. Salameh, W.A.; Mastrogiannis, D.S. Maternal hyperlipidemia in pregnancy. Clin. Obstet. Gynecol. 1994, 37, 66-77. [CrossRef] [PubMed]

90. Bestwick, J.P.; Huttly, W.J.; Morris, J.K.; Wald, N.J. Prevention of neural tube defects: A cross-sectional study of the uptake of folic acid supplementation in nearly half a million women. PLoS ONE 2014, 9, e89354. [CrossRef] [PubMed]

91. Prevention of neural tube defects: Results of the medical research council vitamin study. Mrc vitamin study research group. Lancet 1991, 338, 131-137.

92. Li, Z.; Ye, R.; Zhang, L.; Li, H.; Liu, J.; Ren, A. Folic acid supplementation during early pregnancy and the risk of gestational hypertension and preeclampsia. Hypertension 2013, 61, 873-879. [CrossRef] [PubMed]

93. Wang, Y.; Zhao, N.; Qiu, J.; He, X.; Zhou, M.; Cui, H.; Lv, L.; Lin, X.; Zhang, C.; Zhang, H.; et al. Folic acid supplementation and dietary folate intake, and risk of preeclampsia. Eur. J. Clin. Nutr. 2015, 69, 1145-1150. [PubMed]

94. Scholl, T.O.; Hediger, M.L.; Schall, J.I.; Khoo, C.S.; Fischer, R.L. Dietary and serum folate: Their influence on the outcome of pregnancy. Am. J. Clin. Nutr. 1996, 63, 520-525. [PubMed]

95. Kim, M.W.; Ahn, K.H.; Ryu, K.J.; Hong, S.C.; Lee, J.S.; Nava-Ocampo, A.A.; Oh, M.J.; Kim, H.J. Preventive effects of folic acid supplementation on adverse maternal and fetal outcomes. PLoS ONE 2014, 9, e97273. [CrossRef] [PubMed]

96. Chong, M.F.; Wong, J.X.; Colega, M.; Chen, L.W.; van Dam, R.M.; Tan, C.S.; Lim, A.L.; Cai, S.; Broekman, B.F.; Lee, Y.S.; et al. Relationships of maternal folate and vitamin b12 status during pregnancy with perinatal depression: The gusto study. J. Psychiatr. Res. 2014, 55, 110-116. [PubMed]

97. Siega-Riz, A.M.; Savitz, D.A.; Zeisel, S.H.; Thorp, J.M.; Herring, A. Second trimester folate status and preterm birth. Am. J. Obstet. Gynecol. 2004, 191, 1851-1857. [CrossRef] [PubMed]

98. Naimi, A.I.; Auger, N. Population-wide folic acid fortification and preterm birth: Testing the folate depletion hypothesis. Am. J. Public Health 2015, 105, 793-795. [CrossRef] [PubMed] 
99. Dunlop, A.L.; Kramer, M.R.; Hogue, C.J.; Menon, R.; Ramakrishan, U. Racial disparities in preterm birth: An overview of the potential role of nutrient deficiencies. Acta Obstet. Gynecol. Scand. 2011, 90, 1332-1341. [CrossRef] [PubMed]

100. Rozendaal, A.M.; van Essen, A.J.; te Meerman, G.J.; Bakker, M.K.; van der Biezen, J.J.; Goorhuis-Brouwer, S.M.; Vermeij-Keers, C.; de Walle, H.E. Periconceptional folic acid associated with an increased risk of oral clefts relative to non-folate related malformations in the northern netherlands: A population based case-control study. Eur. J. Epidemiol. 2013, 28, 875-887. [CrossRef] [PubMed]

101. Veeranki, S.P.; Gebretsadik, T.; Dorris, S.L.; Mitchel, E.F.; Hartert, T.V.; Cooper, W.O.; Tylavsky, F.A.; Dupont, W.; Hartman, T.J.; Carroll, K.N. Association of folic acid supplementation during pregnancy and infant bronchiolitis. Am. J. Epidemiol. 2014, 179, 938-946. [CrossRef] [PubMed]

102. McKay, J.A.; Wong, Y.K.; Relton, C.L.; Ford, D.; Mathers, J.C. Maternal folate supply and sex influence gene-specific DNA methylation in the fetal gut. Mol. Nutr. Food Res. 2011, 55, 1717-1723. [CrossRef] [PubMed]

103. Hoyo, C.; Murtha, A.P.; Schildkraut, J.M.; Jirtle, R.L.; Demark-Wahnefried, W.; Forman, M.R.; Iversen, E.S.; Kurtzberg, J.; Overcash, F.; Huang, Z.; et al. Methylation variation at igf2 differentially methylated regions and maternal folic acid use before and during pregnancy. Epigenetics Off. J. DNA Methylation Soc. 2011, 6, 928-936.

104. McKay, J.A.; Waltham, K.J.; Williams, E.A.; Mathers, J.C. Folate depletion during pregnancy and lactation reduces genomic DNA methylation in murine adult offspring. Genes Nutr. 2011, 6, 189-196. [CrossRef] [PubMed]

105. Maloney, C.A.; Hay, S.M.; Rees, W.D. Folate deficiency during pregnancy impacts on methyl metabolism without affecting global DNA methylation in the rat fetus. Br. J. Nutr. 2007, 97, 1090-1098. [CrossRef] [PubMed]

106. McKay, J.A.; Xie, L.; Harris, S.; Wong, Y.K.; Ford, D.; Mathers, J.C. Blood as a surrogate marker for tissue-specific DNA methylation and changes due to folate depletion in post-partum female mice. Mol. Nutr. Food Res. 2011, 55, 1026-1035. [CrossRef] [PubMed]

107. Haggarty, P.; Hoad, G.; Campbell, D.M.; Horgan, G.W.; Piyathilake, C.; McNeill, G. Folate in pregnancy and imprinted gene and repeat element methylation in the offspring. Am. J. Clin. Nutr. 2013, 97, 94-99. [CrossRef] [PubMed]

108. Chalitchagorn, K.; Shuangshoti, S.; Hourpai, N.; Kongruttanachok, N.; Tangkijvanich, P.; Thong-ngam, D.; Voravud, N.; Sriuranpong, V.; Mutirangura, A. Distinctive pattern of line-1 methylation level in normal tissues and the association with carcinogenesis. Oncogene 2004, 23, 8841-8846. [CrossRef] [PubMed]

109. He, H.; Kim, J. Regulation and function of the peg3 imprinted domain. Genom. Inform. 2014, 12, $105-113$. [CrossRef] [PubMed]

110. Temple, I.K.; Shield, J.P. Transient neonatal diabetes, a disorder of imprinting. J. Med. Genet. 2002, 39, 872-875. [CrossRef] [PubMed]

111. Hammoud, S.S.; Purwar, J.; Pflueger, C.; Cairns, B.R.; Carrell, D.T. Alterations in sperm DNA methylation patterns at imprinted loci in two classes of infertility. Fertil. Steril. 2010, 94, 1728-1733. [CrossRef] [PubMed]

112. Kim, J.; Bretz, C.L.; Lee, S. Epigenetic instability of imprinted genes in human cancers. Nucleic Acids Res. 2015, 43, 10689-10699. [CrossRef] [PubMed]

113. Ba, Y.; Yu, H.; Liu, F.; Geng, X.; Zhu, C.; Zhu, Q.; Zheng, T.; Ma, S.; Wang, G.; Li, Z.; et al. Relationship of folate, vitamin b12 and methylation of insulin-like growth factor-ii in maternal and cord blood. Eur. J. Clin. Nutr. 2011, 65, 480-485. [PubMed]

114. Dunlop, A.L.; Taylor, R.N.; Tangpricha, V.; Fortunato, S.; Menon, R. Maternal vitamin d, folate, and polyunsaturated fatty acid status and bacterial vaginosis during pregnancy. Infect. Dis. Obstet. Gynecol. 2011. [CrossRef] [PubMed]

115. Thota, C.; Menon, R.; Fortunato, S.J.; Brou, L.; Lee, J.E.; Al-Hendy, A. 1,25-dihydroxyvitamin d deficiency is associated with preterm birth in african american and caucasian women. Reprod. Sci. 2014, 21, 244-250. [CrossRef] [PubMed]

116. Chen, Y.H.; Fu, L.; Hao, J.H.; Yu, Z.; Zhu, P.; Wang, H.; Xu, Y.Y.; Zhang, C.; Tao, F.B.; Xu, D.X. Maternal vitamin d deficiency during pregnancy elevates the risks of small for gestational age and low birth weight infants in chinese population. J. Clin. Endocrinol. Metab. 2015, 100, 1912-1919. [CrossRef] [PubMed] 
117. Bodnar, L.M.; Platt, R.W.; Simhan, H.N. Early-pregnancy vitamin d deficiency and risk of preterm birth subtypes. Obstet. Gynecol. 2015, 125, 439-447. [CrossRef] [PubMed]

118. Zhu, T.; Liu, T.J.; Ge, X.; Kong, J.; Zhang, L.J.; Zhao, Q. High prevalence of maternal vitamin d deficiency in preterm births in northeast china, shenyang. Int. J. Clin. Exp. Pathol. 2015, 8, 1459-1465. [PubMed]

119. Thorne-Lyman, A.; Fawzi, W.W. Vitamin d during pregnancy and maternal, neonatal and infant health outcomes: A systematic review and meta-analysis. Paediatr. Perinat. Epidemiol. 2012, 26, 75-90. [CrossRef] [PubMed]

120. Paterson, C.R.; Ayoub, D. Congenital rickets due to vitamin d deficiency in the mothers. Clin. Nutr. 2015, 34, 793-798. [CrossRef] [PubMed]

121. Krishnaveni, G.V.; Veena, S.R.; Winder, N.R.; Hill, J.C.; Noonan, K.; Boucher, B.J.; Karat, S.C.; Fall, C.H. Maternal vitamin d status during pregnancy and body composition and cardiovascular risk markers in indian children: The mysore parthenon study. Am. J. Clin. Nutr. 2011, 93, 628-635. [CrossRef] [PubMed]

122. Tornhammar, P.; Ueda, P.; Hult, M.; Simila, H.; Eyles, D.; Norman, M. Season of birth, neonatal vitamin d status, and cardiovascular disease risk at $35 \mathrm{y}$ of age: A cohort study from sweden. Am. J. Clin. Nutr. 2014, 99, 472-478. [CrossRef] [PubMed]

123. Maslova, E.; Hansen, S.; Jensen, C.B.; Thorne-Lyman, A.L.; Strom, M.; Olsen, S.F. Vitamin d intake in mid-pregnancy and child allergic disease-A prospective study in 44,825 danish mother-child pairs. BMC Pregnancy Childbirth 2013. [CrossRef] [PubMed]

124. Fernell, E.; Bejerot, S.; Westerlund, J.; Miniscalco, C.; Simila, H.; Eyles, D.; Gillberg, C.; Humble, M.B. Autism spectrum disorder and low vitamin d at birth: A sibling control study. Mol. Autism 2015. [CrossRef] [PubMed]

125. Novakovic, B.; Galati, J.C.; Chen, A.; Morley, R.; Craig, J.M.; Saffery, R. Maternal vitamin d predominates over genetic factors in determining neonatal circulating vitamin d concentrations. Am. J. Clin. Nutr. 2012, 96, 188-195. [CrossRef] [PubMed]

126. Hewison, M. Vitamin d and immune function: An overview. Proc. Nutr. Soc. 2012, 71, 50-61. [CrossRef] [PubMed]

127. Liong, S.; Di Quinzio, M.K.; Fleming, G.; Permezel, M.; Georgiou, H.M. Is vitamin d binding protein a novel predictor of labour? PLoS ONE 2013, 8, e76490. [CrossRef] [PubMed]

128. Liong, S.; Di Quinzio, M.K.; Fleming, G.; Permezel, M.; Rice, G.E.; Georgiou, H.M. New biomarkers for the prediction of spontaneous preterm labour in symptomatic pregnant women: A comparison with fetal fibronectin. BJOG 2015, 122, 370-379. [CrossRef] [PubMed]

129. Bobbitt, K.R.; Peters, R.M.; Li, J.; Rao, S.D.; Woodcroft, K.J.; Cassidy-Bushrow, A.E. Early pregnancy vitamin $\mathrm{d}$ and patterns of antenatal inflammation in african-american women. J. Reprod. Immunol. 2015, 107, 52-58. [CrossRef] [PubMed]

130. Vijayendra Chary, A.; Hemalatha, R.; Seshacharyulu, M.; Vasudeva Murali, M.; Jayaprakash, D.; Dinesh Kumar, B. Reprint of "vitamin d deficiency in pregnant women impairs regulatory t cell function". J. Steroid Biochem. Mol. Biol. 2015, 148, 194-201. [CrossRef] [PubMed]

131. Bodnar, L.M.; Catov, J.M.; Simhan, H.N.; Holick, M.F.; Powers, R.W.; Roberts, J.M. Maternal vitamin d deficiency increases the risk of preeclampsia. J. Clin. Endocrinol. Metab. 2007, 92, 3517-3522. [CrossRef] [PubMed]

132. Bodnar, L.M.; Simhan, H.N. Vitamin d may be a link to black-white disparities in adverse birth outcomes. Obstet. Gynecol. Surv. 2010, 65, 273-284. [CrossRef] [PubMed]

133. Perez-Ferre, N.; Torrejon, M.J.; Fuentes, M.; Fernandez, M.D.; Ramos, A.; Bordiu, E.; del Valle, L.; Rubio, M.A.; Bedia, A.R.; Montanez, C.; et al. Association of low serum 25-hydroxyvitamin d levels in pregnancy with glucose homeostasis and obstetric and newborn outcomes. Endocr. Pract. 2012, 18, 676-684.

134. Bodnar, L.M.; Simhan, H.N.; Powers, R.W.; Frank, M.P.; Cooperstein, E.; Roberts, J.M. High prevalence of vitamin $d$ insufficiency in black and white pregnant women residing in the northern united states and their neonates. J. Nutr. 2007, 137, 447-452. [PubMed]

135. Mozhui, K.; Smith, A.K.; Tylavsky, F.A. Ancestry dependent DNA methylation and influence of maternal nutrition. PLoS ONE 2015, 10, e0118466. [CrossRef] [PubMed]

136. Tong, V.T.; Dietz, P.M.; Morrow, B.; D’Angelo, D.V.; Farr, S.L.; Rockhill, K.M.; England, L.J. Trends in smoking before, during, and after pregnancy-pregnancy risk assessment monitoring system, united states, 40 sites, 2000-2010. MMWR Surveill. Summ. 2013, 62, 1-19. [PubMed] 
137. Aliyu, M.H.; Salihu, H.M.; Wilson, R.E.; Alio, A.P.; Kirby, R.S. The risk of intrapartum stillbirth among smokers of advanced maternal age. Arch. Gynecol. Obstet. 2008, 278, 39-45. [CrossRef] [PubMed]

138. Rua Ede, A.; Porto, M.L.; Ramos, J.P.; Nogueira, B.V.; Meyrelles, S.S.; Vasquez, E.C.; Pereira, T.C. Effects of tobacco smoking during pregnancy on oxidative stress in the umbilical cord and mononuclear blood cells of neonates. J. Biomed. Sci. 2014. [CrossRef]

139. Shinjo, A.; Ventura, W.; Koide, K.; Hori, K.; Yotsumoto, J.; Matsuoka, R.; Ichizuka, K.; Sekizawa, A. Maternal smoking and placental expression of a panel of genes related to angiogenesis and oxidative stress in early pregnancy. Fetal Diagn. Ther. 2014, 35, 289-295. [CrossRef] [PubMed]

140. Marufu, T.C.; Ahankari, A.; Coleman, T.; Lewis, S. Maternal smoking and the risk of still birth: Systematic review and meta-analysis. BMC Public Health 2015. [CrossRef] [PubMed]

141. Isayama, T.; Shah, P.S.; Ye, X.Y.; Dunn, M.; Da Silva, O.; Alvaro, R.; Lee, S.K. Adverse impact of maternal cigarette smoking on preterm infants: A population-based cohort study. Am. J. Perinatol. 2015, 32, 1105-1111. [CrossRef] [PubMed]

142. Kyrklund-Blomberg, N.B.; Granath, F.; Cnattingius, S. Maternal smoking and causes of very preterm birth. Acta Obstet. Gynecol. Scand. 2005, 84, 572-577. [PubMed]

143. Smith, L.K.; Draper, E.S.; Evans, T.A.; Field, D.J.; Johnson, S.J.; Manktelow, B.N.; Seaton, S.E.; Marlow, N.; Petrou, S.; Boyle, E.M. Associations between late and moderately preterm birth and smoking, alcohol, drug use and diet: A population-based case-cohort study. Arch. Dis. Child. Fetal Neonat. Ed. 2015. [CrossRef] [PubMed]

144. Anthopolos, R.; Edwards, S.E.; Miranda, M.L. Effects of maternal prenatal smoking and birth outcomes extending into the normal range on academic performance in fourth grade in north carolina, USA. Paediatr. Perinat. Epidemiol. 2013, 27, 564-574. [CrossRef] [PubMed]

145. Hogberg, L.; Cnattingius, S.; Lundholm, C.; D'Onofrio, B.M.; Langstrom, N.; Iliadou, A.N. Effects of maternal smoking during pregnancy on offspring blood pressure in late adolescence. J. Hypertens. 2012, 30, 693-699. [CrossRef] [PubMed]

146. Sun, Y.V.; Smith, A.K.; Conneely, K.N.; Chang, Q.; Li, W.; Lazarus, A.; Smith, J.A.; Almli, L.M.; Binder, E.B.; Klengel, T.; et al. Epigenomic association analysis identifies smoking-related DNA methylation sites in african americans. Hum. Genet. 2013, 132, 1027-1037. [PubMed]

147. Joubert, B.R.; Haberg, S.E.; Nilsen, R.M.; Wang, X.; Vollset, S.E.; Murphy, S.K.; Huang, Z.; Hoyo, C.; Midttun, O.; Cupul-Uicab, L.A.; et al. 450k epigenome-wide scan identifies differential DNA methylation in newborns related to maternal smoking during pregnancy. Environ. Health Perspect. 2012, 120, 1425-1431. [PubMed]

148. Ivorra, C.; Fraga, M.F.; Bayon, G.F.; Fernandez, A.F.; Garcia-Vicent, C.; Chaves, F.J.; Redon, J.; Lurbe, E. DNA methylation patterns in newborns exposed to tobacco in utero. J. Transl. Med. 2015. [CrossRef] [PubMed]

149. Kupers, L.K.; Xu, X.; Jankipersadsing, S.A.; Vaez, A.; la Bastide-van Gemert, S.; Scholtens, S.; Nolte, I.M.; Richmond, R.C.; Relton, C.L.; Felix, J.F.; et al. DNA methylation mediates the effect of maternal smoking during pregnancy on birthweight of the offspring. Int. J. Epidemiol. 2015, 44, 1224-1237. [PubMed]

150. Flom, J.; Ferris, J.; Gonzalez, K.; Santella, R.; Terry, M.B. Prenatal tobacco smoke exposure and genomewide methylation in adulthood. Cancer Epidemiol. Biomark. Prev. 2011, 20, 720-720.

151. Lee, K.W.; Richmond, R.; Hu, P.; French, L.; Shin, J.; Bourdon, C.; Reischl, E.; Waldenberger, M.; Zeilinger, S.; Gaunt, T.; et al. Prenatal exposure to maternal cigarette smoking and DNA methylation: Epigenome-wide association in a discovery sample of adolescents and replication in an independent cohort at birth through 17 years of age. Environ. Health Perspect. 2015, 123, 193-199.

152. Bhuvaneswar, C.G.; Chang, G.; Epstein, L.A.; Stern, T.A. Alcohol use during pregnancy: Prevalence and impact. Prim. Care Companion J. Clin. Psychiatry 2007, 9, 455-460. [CrossRef] [PubMed]

153. Orsi, L.; Rudant, J.; Ajrouche, R.; Leverger, G.; Baruchel, A.; Nelken, B.; Pasquet, M.; Michel, G.; Bertrand, Y.; Ducassou, S.; et al. Parental smoking, maternal alcohol, coffee and tea consumption during pregnancy, and childhood acute leukemia: The estelle study. Cancer Causes Control CCC 2015, 26, 1003-1017. [PubMed]

154. Flak, A.L.; Su, S.; Bertrand, J.; Denny, C.H.; Kesmodel, U.S.; Cogswell, M.E. The association of mild, moderate, and binge prenatal alcohol exposure and child neuropsychological outcomes: A meta-analysis. Alcohol. Clin. Exp. Res. 2014, 38, 214-226. [CrossRef] [PubMed]

155. Mason, S.; Zhou, F.C. Editorial: Genetics and epigenetics of fetal alcohol spectrum disorders. Front. Genet. 2015. [CrossRef] [PubMed] 
156. Kesmodel, U.; Olsen, S.F.; Secher, N.J. Does alcohol increase the risk of preterm delivery? Epidemiology 2000, 11, 512-518. [CrossRef] [PubMed]

157. Lundsberg, L.S.; Illuzzi, J.L.; Belanger, K.; Triche, E.W.; Bracken, M.B. Low-to-moderate prenatal alcohol consumption and the risk of selected birth outcomes: A prospective cohort study. Ann. Epidemiol. 2015. [CrossRef] [PubMed]

158. Curtis, B.J.; Zahs, A.; Kovacs, E.J. Epigenetic targets for reversing immune defects caused by alcohol exposure. Alcohol Res. Curr. Rev. 2013, 35, 97-113.

159. Harlaar, N.; Hutchison, K.E. Alcohol and the methylome: Design and analysis considerations for research using human samples. Drug Alcohol Depend. 2013, 133, 305-316. [CrossRef] [PubMed]

160. Lee, B.Y.; Park, S.Y.; Ryu, H.M.; Shin, C.Y.; Ko, K.N.; Han, J.Y.; Koren, G.; Cho, Y.H. Changes in the methylation status of dat, sert, and mecp2 gene promoters in the blood cell in families exposed to alcohol during the periconceptional period. Alcohol. Clin. Exp. Res. 2015, 39, 239-250. [CrossRef] [PubMed]

161. Burns, E.R.; Farr, S.L.; Howards, P.P.; Centers for Disease Control and Prevention (CDCP). Stressful life events experienced by women in the year before their infants' births-United States, 2000-2010. MMWR Morb. Mortal. Wkly. Rep. 2015, 64, 247-251. [PubMed]

162. Lobel, M.; Cannella, D.L.; Graham, J.E.; DeVincent, C.; Schneider, J.; Meyer, B.A. Pregnancy-specific stress, prenatal health behaviors, and birth outcomes. Health Psychol. Off. J. Div. Health Psychol. Am. Psychol. Assoc. 2008, 27, 604-615. [CrossRef] [PubMed]

163. Dunn, A.J. The hpa axis and the immune system: A perspective. NeuroImmune Biol. 2007, 7, 3-15.

164. Charmandari, E.; Tsigos, C.; Chrousos, G. Endocrinology of the stress response. Annu. Rev. Physiol. 2005, 67, 259-284. [CrossRef] [PubMed]

165. Tsigos, C.; Chrousos, G.P. Hypothalamic-pituitary-adrenal axis, neuroendocrine factors and stress. J. Psychosom. Res. 2002, 53, 865-871. [CrossRef]

166. Boumpas, D.T.; Chrousos, G.P.; Wilder, R.L.; Cupps, T.R.; Balow, J.E. Glucocorticoid therapy for immune-mediated diseases: Basic and clinical correlates. Ann. Intern. Med. 1993, 119, 1198-1208. [CrossRef] [PubMed]

167. Bloch, M.; Daly, R.C.; Rubinow, D.R. Endocrine factors in the etiology of postpartum depression. Compr. Psychiatry 2003, 44, 234-246. [CrossRef]

168. Reis, F.M.; Fadalti, M.; Florio, P.; Petraglia, F. Putative role of placental corticotropin-releasing factor in the mechanisms of human parturition. J. Soc. Gynecol. Investig. 1999, 6, 109-119. [CrossRef]

169. Appleton, A.A.; Armstrong, D.A.; Lesseur, C.; Lee, J.; Padbury, J.F.; Lester, B.M.; Marsit, C.J. Patterning in placental 11-b hydroxysteroid dehydrogenase methylation according to prenatal socioeconomic adversity. PLOS ONE 2013, 8, e74691. [CrossRef] [PubMed]

170. Vidal, A.C.; Benjamin Neelon, S.E.; Liu, Y.; Tuli, A.M.; Fuemmeler, B.F.; Hoyo, C.; Murtha, A.P.; Huang, Z.; Schildkraut, J.; Overcash, F.; et al. Maternal stress, preterm birth, and DNA methylation at imprint regulatory sequences in humans. Genet. Epigenetics 2014, 6, 37-44.

171. Cohen, S.; Kamarck, T.; Mermelstein, R. A global measure of perceived stress. J. Health Soc. Behav. 1983, 385-396. [CrossRef]

172. Chen, C.P.; Su, Y.N.; Lin, M.H.; Wang, T.Y.; Chern, S.R.; Kuo, Y.L.; Chen, Y.T.; Wang, W. Detection of altered methylation status at 11p15.5 and 7q32 in placental mesenchymal dysplasia. Taiwan. J. Obstet. Gynecol. 2014, 53, 68-73. [CrossRef] [PubMed]

173. Cao-Lei, L.; Massart, R.; Suderman, M.J.; Machnes, Z.; Elgbeili, G.; Laplante, D.P.; Szyf, M.; King, S. DNA methylation signatures triggered by prenatal maternal stress exposure to a natural disaster: Project ice storm. PLoS ONE 2014, 9, e107653. [CrossRef] [PubMed]

174. Christianson, S.; Marren, J. The impact of event scale-revised (IES-R). Medsurg. Nurs. 2012, 21, 321-322. [PubMed]

175. Miller, G.E.; Chen, E.; Zhou, E.S. If it goes up, must it come down? Chronic stress and the hypothalamic-pituitary-adrenocortical axis in humans. Psychol. Bull. 2007, 133, 25-45. [PubMed]

176. Han, A.; Stewart, D.E. Maternal and fetal outcomes of intimate partner violence associated with pregnancy in the latin american and caribbean region. Int. J. Gynaecol. Obstet. Off. Organ Int. Fed. Gynaecol. Obstet. 2014, 124, 6-11. [CrossRef] [PubMed] 
177. Shah, P.S.; Shah, J.; Knowledge Synthesis Group on Determinants of Preterm/LBW Births. Maternal exposure to domestic violence and pregnancy and birth outcomes: A systematic review and meta-analyses. J. Women's Health 2010, 19, 2017-2031. [CrossRef] [PubMed]

178. Radtke, K.M.; Ruf, M.; Gunter, H.M.; Dohrmann, K.; Schauer, M.; Meyer, A.; Elbert, T. Transgenerational impact of intimate partner violence on methylation in the promoter of the glucocorticoid receptor. Transl. Psychiatry 2011. [CrossRef] [PubMed]

179. Dibaba, Y.; Fantahun, M.; Hindin, M.J. The association of unwanted pregnancy and social support with depressive symptoms in pregnancy: Evidence from rural southwestern ethiopia. BMC Pregnancy Childbirth 2013. [CrossRef] [PubMed]

180. Ghosh, J.K.; Wilhelm, M.H.; Dunkel-Schetter, C.; Lombardi, C.A.; Ritz, B.R. Paternal support and preterm birth, and the moderation of effects of chronic stress: A study in los angeles county mothers. Arch. Women's Ment. Health 2010, 13, 327-338. [CrossRef] [PubMed]

181. Pires, R.; Araujo-Pedrosa, A.; Canavarro, M.C. Examining the links between perceived impact of pregnancy, depressive symptoms, and quality of life during adolescent pregnancy: The buffering role of social support. Matern. Child Health J. 2014, 18, 789-800. [CrossRef] [PubMed]

182. Straughen, J.K.; Caldwell, C.H.; Young, A.A., Jr.; Misra, D.P. Partner support in a cohort of african american families and its influence on pregnancy outcomes and prenatal health behaviors. BMC Pregnancy Childbirth 2013. [CrossRef] [PubMed]

183. Giesbrecht, G.F.; Poole, J.C.; Letourneau, N.; Campbell, T.; Kaplan, B.J.; Team, A.P.S. The buffering effect of social support on hypothalamic-pituitary-adrenal axis function during pregnancy. Psychosom. Med. 2013, 75, 856-862. [CrossRef] [PubMed]

184. Field, T. Prenatal depression effects on early development: A review. Infant Behav. Dev. 2011, 34, 1-14. [CrossRef] [PubMed]

185. Narendran, S.; Nagarathna, R.; Narendran, V.; Gunasheela, S.; Nagendra, H.R. Efficacy of yoga on pregnancy outcome. J. Altern. Complement. Med. 2005, 11, 237-244. [CrossRef] [PubMed]

186. Field, T.; Hernandez-Reif, M.; Diego, M. Newborns of depressed mothers who received moderate versus light pressure massage during pregnancy. Infant Behav. Dev. 2006, 29, 54-58. [CrossRef] [PubMed]

187. Field, T.; Diego, M.; Hernandez-Reif, M.; Deeds, O.; Figueiredo, B. Pregnancy massage reduces prematurity, low birthweight and postpartum depression. Infant Behav. Dev. 2009, 32, 454-460. [CrossRef] [PubMed]

188. Tanner-Smith, E.E.; Steinka-Fry, K.T.; Lipsey, M.W. The effects of centeringpregnancy group prenatal care on gestational age, birth weight, and fetal demise. Matern. Child Health J. 2014, 18, 801-809. [CrossRef] [PubMed]

189. Grady, M.A.; Bloom, K.C. Pregnancy outcomes of adolescents enrolled in a centeringpregnancy program. J. Midwifery Women's Health 2004, 49, 412-420. [CrossRef] [PubMed]

190. Walton, R.B.; Shaffer, S.; Heaton, J. Group prenatal care outcomes in a military population: A retrospective cohort study. Mil. Med. 2015, 180, 825-829. [CrossRef] [PubMed]

191. Field, T.; Hernandez-Reif, M.; Diego, M.; Schanberg, S.; Kuhn, C. Cortisol decreases and serotonin and dopamine increase following massage therapy. Int. J. Neurosc. 2005, 115, 1397-1413. [CrossRef] [PubMed]

192. Heberlein, E.C.; Picklesimer, A.H.; Billings, D.L.; Covington-Kolb, S.; Farber, N.; Frongillo, E.A. The comparative effects of group prenatal care on psychosocial outcomes. Arch. Women's Ment. Health 2016, 19, 259-269. [CrossRef] [PubMed]

193. Goldenberg, R.L.; Cliver, S.P.; Mulvihill, F.X.; Hickey, C.A.; Hoffman, H.J.; Klerman, L.V.; Johnson, M.J. Medical, psychosocial, and behavioral risk factors do not explain the increased risk for low birth weight among black women. Am. J. Obstet. Gynecol. 1996, 175, 1317-1324. [CrossRef]

194. Marret, S.; Ancel, P.Y.; Marpeau, L.; Marchand, L.; Pierrat, V.; Larroque, B.; Foix-L'Helias, L.; Thiriez, G.; Fresson, J.; Alberge, C.; et al. Neonatal and 5-year outcomes after birth at 30-34 weeks of gestation. Obstet. Gynecol. 2007, 110, 72-80. [PubMed]

195. Hogan, V.K.; Richardson, J.L.; Ferre, C.D.; Durant, T.; Boisseau, M. A public health framework for addressing black and white disparities in preterm delivery. J. Am. Med. Womens Assoc. 2001, 56, 177-180. [PubMed]

196. Green, N.S.; Damus, K.; Simpson, J.L.; Iams, J.; Reece, E.A.; Hobel, C.J.; Merkatz, I.R.; Greene, M.F.; Schwarz, R.H. Research agenda for preterm birth: Recommendations from the march of dimes. Am. J. Obstet. Gynecol. 2005, 193, 626-635. [CrossRef] [PubMed] 
197. Kramer, M.R.; Hogue, C.R. What causes racial disparities in very preterm birth? A biosocial perspective. Epidemiol. Rev. 2009, 31, 84-98. [PubMed]

198. Anum, E.A.; Springel, E.H.; Shriver, M.D.; Strauss, J.F., 3rd. Genetic contributions to disparities in preterm birth. Pediatr. Res. 2009, 65, 1-9. [PubMed]

199. Adkins, R.M.; Krushkal, J.; Tylavsky, F.A.; Thomas, F. Racial differences in gene-specific DNA methylation levels are present at birth. Birth Defects Res. Part A Clin. Mol. Teratol. 2011, 91, 728-736. [CrossRef] [PubMed]

200. Tehranifar, P.; Wu, H.C.; Fan, X.; Flom, J.D.; Ferris, J.S.; Cho, Y.H.; Gonzalez, K.; Santella, R.M.; Terry, M.B. Early life socioeconomic factors and genomic DNA methylation in mid-life. Epigenetics Off. J. DNA Methylation Soc. 2013, 8, 23-27. [CrossRef] [PubMed]

201. Miller, G.E.; Chen, E.; Fok, A.K.; Walker, H.; Lim, A.; Nicholls, E.F.; Cole, S.; Kobor, M.S. Low early-life social class leaves a biological residue manifested by decreased glucocorticoid and increased proinflammatory signaling. Proc. Natl. Acad. Sci. USA 2009, 106, 14716-14721. [CrossRef] [PubMed]

202. Geronimus, A.T. Black/white differences in the relationship of maternal age to birthweight: A population-based test of the weathering hypothesis. Soc. Sci. Med. 1996, 42, 589-597. [CrossRef]

203. Geronimus, A.T. The weathering hypothesis and the health of african-american women and infants: Evidence and speculations. Ethn. Dis. 1991, 2, 207-221.

204. Holzman, C.; Eyster, J.; Kleyn, M.; Messer, L.C.; Kaufman, J.S.; Laraia, B.A.; O'Campo, P.; Burke, J.G.; Culhane, J.; Elo, I.T. Maternal weathering and risk of preterm delivery. Am. J. Public Health 2009, 99, 1864-1871. [CrossRef] [PubMed]

205. Miller, M.W.; Sadeh, N. Traumatic stress, oxidative stress and post-traumatic stress disorder: Neurodegeneration and the accelerated-aging hypothesis. Mol. Psychiatry 2014, 19, 1156-1162. [CrossRef] [PubMed]

206. Chen, X.; Velez, J.C.; Barbosa, C.; Pepper, M.; Andrade, A.; Stoner, L.; De Vivo, I.; Gelaye, B.; Williams, M.A. Smoking and perceived stress in relation to short salivary telomere length among caregivers of children with disabilities. Stress 2015, 18, 20-28. [CrossRef] [PubMed]

207. Boks, M.P.; van Mierlo, H.C.; Rutten, B.P.; Radstake, T.R.; De Witte, L.; Geuze, E.; Horvath, S.; Schalkwyk, L.C.; Vinkers, C.H.; Broen, J.C.; et al. Longitudinal changes of telomere length and epigenetic age related to traumatic stress and post-traumatic stress disorder. Psychoneuroendocrinology 2015, 51, 506-512. [PubMed]

208. Love, C.; David, R.J.; Rankin, K.M.; Collins, J.W., Jr. Exploring weathering: Effects of lifelong economic environment and maternal age on low birth weight, small for gestational age, and preterm birth in African-American and white women. Am. J. Epidemiol. 2010, 172, 127-134. [CrossRef] [PubMed]

209. Collins, J.W.; Rankin, K.M.; Hedstrom, A.B. Exploring weathering: The relation of age to low birth weight among first generation and established united states-born mexican-american women. Matern. Child Health J. 2012, 16, 967-972. [CrossRef] [PubMed]

210. Wildsmith, E.M. Testing the weathering hypothesis among mexican-origin women. Ethn. Dis. 2002, 12, 470-479. [PubMed]

211. Ferrari, F.; Facchinetti, F.; Saade, G.; Menon, R. Placental telomere shortening in stillbirth: A sign of premature senescence? J. Matern.-Fetal Neonatal Med. 2016, 29, 1283-1288. [CrossRef] [PubMed]

212. Menon, R.; Yu, J.; Basanta-Henry, P.; Brou, L.; Berga, S.L.; Fortunato, S.J.; Taylor, R.N. Short fetal leukocyte telomere length and preterm prelabor rupture of the membranes. PLoS ONE 2012, 7, e31136. [CrossRef] [PubMed]

213. Friedrich, U.; Schwab, M.; Griese, E.U.; Fritz, P.; Klotz, U. Telomeres in neonates: New insights in fetal hematopoiesis. Pediatr. Res. 2001, 49, 252-256. [CrossRef] [PubMed]

214. Menon, R.; Boldogh, I.; Hawkins, H.K.; Woodson, M.; Polettini, J.; Syed, T.A.; Fortunato, S.J.; Saade, G.R.; Papaconstantinou, J.; Taylor, R.N. Histological evidence of oxidative stress and premature senescence in preterm premature rupture of the human fetal membranes recapitulated in vitro. Am. J. Pathol. 2014, 184, 1740-1751. [CrossRef] [PubMed]

215. Greider, C.W. Telomere length regulation. Annu. Rev. Biochem. 1996, 65, 337-365. [CrossRef] [PubMed]

216. Samassekou, O.; Gadji, M.; Drouin, R.; Yan, J. Sizing the ends: Normal length of human telomeres. Ann. Anat.-Anat. Anz. 2010, 192, 284-291. [CrossRef] [PubMed]

217. Turner, K.J.; Vasu, V.; Greenall, J.; Griffin, D.K. Telomere length analysis and preterm infant health: The importance of assay design in the search for novel biomarkers. Biomark. Med. 2014, 8, 485-498. [CrossRef] [PubMed] 
218. Polettini, J.; Dutta, E.H.; Behnia, F.; Saade, G.R.; Torloni, M.R.; Menon, R. Aging of intrauterine tissues in spontaneous preterm birth and preterm premature rupture of the membranes: A systematic review of the literature. Placenta 2015, 36, 969-973. [CrossRef] [PubMed]

219. Biron-Shental, T.; Sukenik-Halevy, R.; Sharon, Y.; Goldberg-Bittman, L.; Kidron, D.; Fejgin, M.D.; Amiel, A. Short telomeres may play a role in placental dysfunction in preeclampsia and intrauterine growth restriction. Am. J. Obstet. Gynecol. 2010. [CrossRef] [PubMed]

220. Needham, B.L.; Rehkopf, D.; Adler, N.; Gregorich, S.; Lin, J.; Blackburn, E.H.; Epel, E.S. Leukocyte telomere length and mortality in the national health and nutrition examination survey, 1999-2002. Epidemiology 2015, 26, 528-535. [CrossRef] [PubMed]

221. Wentzensen, I.M.; Mirabello, L.; Pfeiffer, R.M.; Savage, S.A. The association of telomere length and cancer: A meta-analysis. Cancer Epidemiol. Biomark. Prev. 2011, 20, 1238-1250. [CrossRef] [PubMed]

222. Honig, L.S.; Kang, M.S.; Schupf, N.; Lee, J.H.; Mayeux, R. Association of shorter leukocyte telomere repeat length with dementia and mortality. Arch. Neurol. 2012, 69, 1332-1339. [CrossRef] [PubMed]

223. D'Mello, M.J.; Ross, S.A.; Briel, M.; Anand, S.S.; Gerstein, H.; Pare, G. Association between shortened leukocyte telomere length and cardiometabolic outcomes: Systematic review and meta-analysis. Circ. Cardiovasc. Genet. 2015, 8, 82-90. [CrossRef] [PubMed]

224. Hou, L.; Joyce, B.T.; Gao, T.; Liu, L.; Zheng, Y.; Penedo, F.J.; Liu, S.; Zhang, W.; Bergan, R.; Qi, D. Blood telomere length attrition and cancer development in the normative aging study cohort. EBioMedicine 2015, 2, 591-596. [CrossRef] [PubMed]

225. Lindqvist, D.; Epel, E.S.; Mellon, S.H.; Penninx, B.W.; Revesz, D.; Verhoeven, J.E.; Reus, V.I.; Lin, J.; Mahan, L.; Hough, C.M.; et al. Psychiatric disorders and leukocyte telomere length: Underlying mechanisms linking mental illness with cellular aging. Neurosci. Biobehav. Rev. 2015, 55, 333-364. [PubMed]

226. Shalev, I.; Caspi, A.; Ambler, A.; Belsky, D.W.; Chapple, S.; Cohen, H.J.; Israel, S.; Poulton, R.; Ramrakha, S.; Rivera, C.D.; et al. Perinatal complications and aging indicators by midlife. Pediatrics 2014, 134, e1315-e1323. [PubMed]

227. Entringer, S.; Epel, E.S.; Kumsta, R.; Lin, J.; Hellhammer, D.H.; Blackburn, E.H.; Wust, S.; Wadhwa, P.D. Stress exposure in intrauterine life is associated with shorter telomere length in young adulthood. Proc. Natl. Acad. Sci. USA 2011, 108, E513-E518. [CrossRef] [PubMed]

228. Entringer, S.; Epel, E.S.; Lin, J.; Buss, C.; Shahbaba, B.; Blackburn, E.H.; Simhan, H.N.; Wadhwa, P.D. Maternal psychosocial stress during pregnancy is associated with newborn leukocyte telomere length. Am. J. Obstet. Gynecol. 2013. [CrossRef] [PubMed]

229. Horvath, S. DNA methylation age of human tissues and cell types. Genome Biol. 2013. [CrossRef] [PubMed]

230. Hannum, G.; Guinney, J.; Zhao, L.; Zhang, L.; Hughes, G.; Sadda, S.; Klotzle, B.; Bibikova, M.; Fan, J.B.; Gao, Y.; et al. Genome-wide methylation profiles reveal quantitative views of human aging rates. Mol. Cell 2013, 49, 359-367. [PubMed]

231. Koch, C.M.; Wagner, W. Epigenetic-aging-signature to determine age in different tissues. Aging 2011, 3, 1018-1027. [CrossRef] [PubMed]

232. Horvath, S.; Garagnani, P.; Bacalini, M.G.; Pirazzini, C.; Salvioli, S.; Gentilini, D.; Di Blasio, A.M.; Giuliani, C.; Tung, S.; Vinters, H.V.; et al. Accelerated epigenetic aging in down syndrome. Aging Cell 2015, 14, 491-495. [PubMed]

233. Simpkin, A.J.; Hemani, G.; Suderman, M.; Gaunt, T.R.; Lyttleton, O.; McArdle, W.L.; Ring, S.M.; Sharp, G.C.; Tilling, K.; Horvath, S.; et al. Prenatal and early life influences on epigenetic age in children: A study of mother-offspring pairs from two cohort studies. Hum. Mol. Genet. 2015. [CrossRef]

234. Schroeder, J.W.; Conneely, K.N.; Cubells, J.C.; Kilaru, V.; Newport, D.J.; Knight, B.T.; Stowe, Z.N.; Brennan, P.A.; Krushkal, J.; Tylavsky, F.A.; et al. Neonatal DNA methylation patterns associate with gestational age. Epigenetics Off. J. DNA Methylation Soc. 2011, 6, 1498-1504. [CrossRef] [PubMed]

235. Lee, H.; Jaffe, A.E.; Feinberg, J.I.; Tryggvadottir, R.; Brown, S.; Montano, C.; Aryee, M.J.; Irizarry, R.A.; Herbstman, J.; Witter, F.R.; et al. DNA methylation shows genome-wide association of nfix, rapgef2 and msrb3 with gestational age at birth. Int. J. Epidemiol. 2012, 41, 188-199. [PubMed]

(C) 2016 by the authors; licensee MDPI, Basel, Switzerland. This article is an open access article distributed under the terms and conditions of the Creative Commons Attribution (CC-BY) license (http:/ / creativecommons.org/licenses/by/4.0/). 